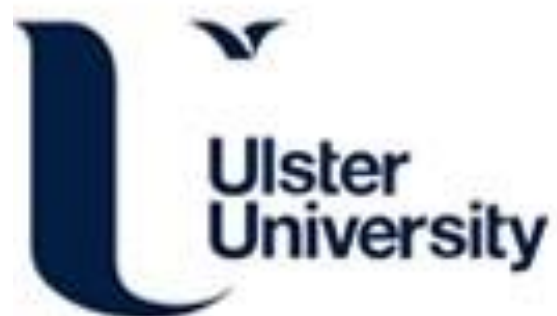

\section{Microbial biosurfactants production, applications and future potential}

Banat, IM., Franzetti, A., Gandolfi, I., Bestetti, G., Martinotti, MG., Fracchia, L., Smyth, TJP., \& Marchant, R. (2010). Microbial biosurfactants production, applications and future potential. Applied Microbiology and Biotechnology, 87(2), 427-444.

Link to publication record in Ulster University Research Portal

\section{Published in:}

Applied Microbiology and Biotechnology

Publication Status:

Published (in print/issue): 01/08/2010

\section{Document Version}

Publisher's PDF, also known as Version of record

\section{General rights}

Copyright for the publications made accessible via Ulster University's Research Portal is retained by the author(s) and / or other copyright owners and it is a condition of accessing these publications that users recognise and abide by the legal requirements associated with these rights.

\section{Take down policy}

The Research Portal is Ulster University's institutional repository that provides access to Ulster's research outputs. Every effort has been made to ensure that content in the Research Portal does not infringe any person's rights, or applicable UK laws. If you discover content in the Research Portal that you believe breaches copyright or violates any law, please contact pure-support@ulster.ac.uk. 


\section{ISSN 0175-7598, Volume 87, Number 2}

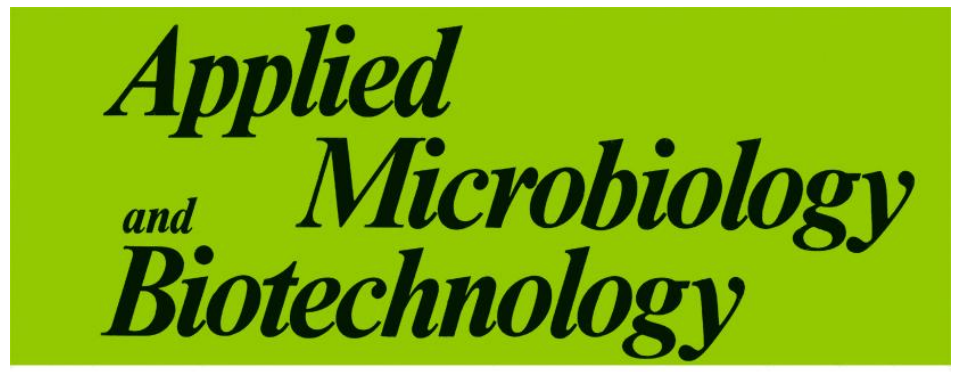

Volume 87 Number 2 June 2010 Mini-Reviews
Saccharomyces cerevisiae and DNA microarray
analyses: what did we learn from it for a better understanding and exploitation of ye
T. Hirasawa - C. Uurusawa $\cdot$ H. Shimizu 391

Recombinant immunotherapeutics: current state and perspectives regarding the feasibility and market Integrated production of xylitol and ethanol using

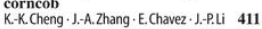
Comparison of hybridization methods and real-time PCR: their value in animal cell line characterizatio H.Böhm-Hofstatter-M. Ischernutter $\cdot$ R.Kunert 419 Microbial biosurfactants production, applications and future polential L.F.Frachia- T. S. Smyth R. R.Marchant 427 Advances in biofilm reactors for production of value-added products
$K$-C.Cheng $A$. D. Demiri $-J$.M. Catchmark 445 Biotechnological production and application of

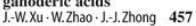
Bacteria causing important diseases of citrus
utilise distinct modes of pathogenesis to attack a common host
A.A.V. Vojnov - A.Morais do Amaral J.M.M. Dow - A.P. Castagnaro A.A.Vojinov-A.Moral
M.R. Marano 467

Inteins, valuable genetic elements in molecular Inteins, valuable genetic
biiology and biotechnology
S.Elleuche.S. Pöggeler n79 479

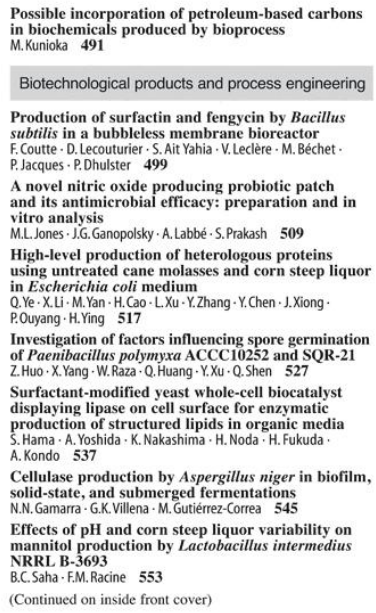

\section{Springer}

This article was published in the above mentioned Springer issue.

The material, including all portions thereof, is protected by copyright; all rights are held exclusively by Springer Science + Business Media.

The material is for personal use only;

commercial use is not permitted.

Unauthorized reproduction, transfer and/or use may be a violation of criminal as well as civil law. 


\title{
Microbial biosurfactants production, applications and future potential
}

\author{
Ibrahim M. Banat • Andrea Franzetti • Isabella Gandolfi • Giuseppina Bestetti • \\ Maria G. Martinotti • Letizia Fracchia • Thomas J. Smyth • Roger Marchant
}

Received: 14 February 2010 /Revised: 24 March 2010 /Accepted: 24 March 2010 /Published online: 28 April 2010

(C) Springer-Verlag 2010

\begin{abstract}
Microorganisms synthesise a wide range of surface-active compounds (SAC), generally called biosurfactants. These compounds are mainly classified according to their molecular weight, physico-chemical properties and mode of action. The low-molecular-weight SACs or biosurfactants reduce the surface tension at the air/water interfaces and the interfacial tension at oil/water interfaces, whereas the high-molecular-weight SACs, also called bioemulsifiers, are more effective in stabilising oil-in-water emulsions. Biosurfactants are attracting much interest due to their potential advantages over their synthetic counterparts in many fields spanning environmental, food, biomedical, and other industrial applications. Their large-scale application and production, however, are currently limited by the high cost of production and by limited understanding of their interactions with cells and with the abiotic environment. In this paper, we review the current knowledge and the latest advances in biosurfactant applications and the biotechnological strategies being developed for improving production processes and future potential.
\end{abstract}

I. M. Banat $(\triangle) \cdot$ T. J. Smyth $\cdot$ R. Marchant

School of Biomedical Sciences, University of Ulster,

Coleraine BT52 1SA, Northern Ireland, UK

e-mail: im.banat@ulster.ac.uk

\author{
A. Franzetti $\cdot$ I. Gandolfi • G. Bestetti \\ Department of Environmental Sciences, \\ University of Milano-Bicocca, \\ Piazza della Scienza 1, \\ 20126 Milano, Italy \\ M. G. Martinotti $\cdot$ L. Fracchia \\ DiSCAFF, Università del Piemonte Orientale, \\ Via Bovio, 6, \\ 28100 Novara, Italy
}

Keywords Biosurfactants · Bioemulsifiers · Surfactants · Emulsifiers

\section{Introduction}

Microbial surface-active compounds

Microbial surface-active compounds are a group of structurally diverse molecules produced by different microorganisms and are mainly classified by their chemical structure and their microbial origin. They are made up of a hydrophilic moiety, comprising an acid, peptide cations, or anions, mono-, di- or polysaccharides and a hydrophobic moiety of unsaturated or saturated hydrocarbon chains or fatty acids. These structures confer a wide range of properties, including the ability to lower surface and interfacial tension of liquids and to form micelles and microemulsions between two different phases. These compounds can be roughly divided into two main classes (Neu 1996): low-molecular-weight compounds called biosurfactants, such as lipopeptides, glycolipids, proteins and high-molecular-weight polymers of polysaccharides, lipopolysaccharides proteins or lipoproteins that are collectively called bioemulsans (Rosenberg and Ron 1997) or bioemulsifiers (Smyth et al. 2010b). The former group includes molecules which can efficiently reduce surface and interfacial tension, while the latter are amphiphilic and polyphilic polymers which are usually more effective in stabilising emulsions of oil-in-water but do not lower the surface tension as much (Smyth et al. 2010a).

The best-studied microbial surfactants are glycolipids. Among these, the best-known compounds are rhamnolipids, trehalolipids, sophorolipids and mannosylerythritol lipids (MELs) (Fig. 1), which contain mono- or disac- 


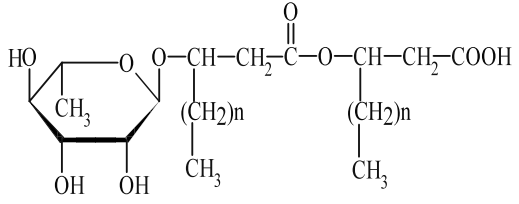

Monorhamnolipids

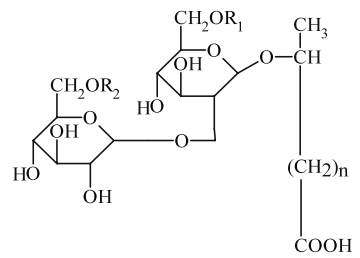

Acidic Sophorolipid

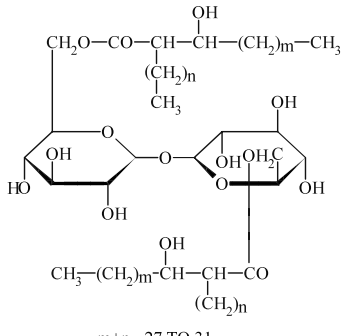

$m+n=27 \mathrm{TO}_{31}$

Trehalose dimycolates

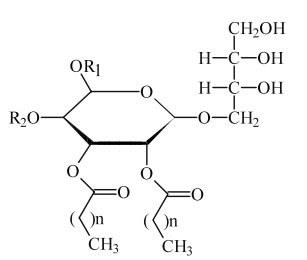

Mannosylerythritol lipids

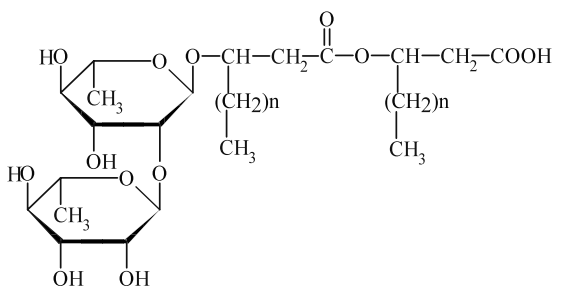

Dirhamnolipid

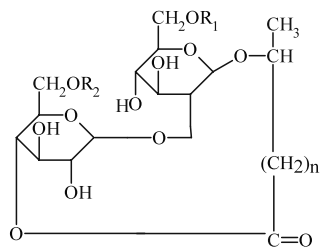

Lactonic Sophorolipid

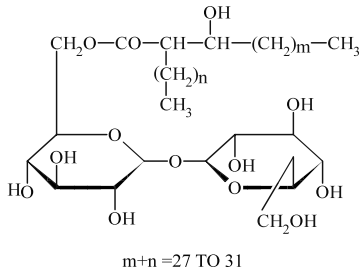

Trehalose monomycolates

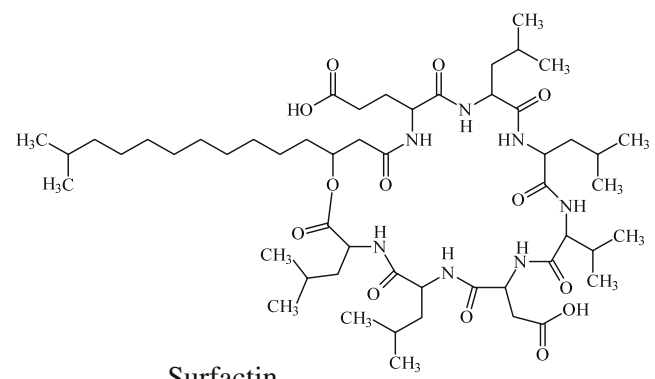

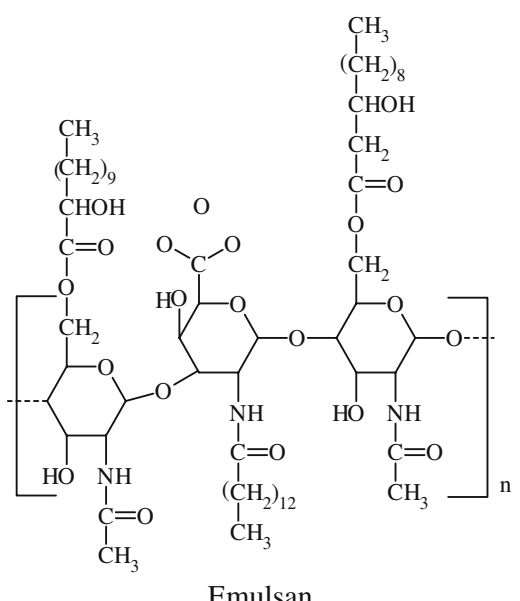

Fig. 1 Chemical structure of the most studied microbial surface-active compounds; mono- and dirhamnolipids, acidic and lactonic sophorolipids, monomycolates trehalose lipid and dimycolates trehalose lipids, mannosylerythritol lipids, surfactin and finally emulsan 
charides, combined with long-chain aliphatic acids or hydroxyaliphatic acids. Rhamnolipid production by $P$ seudomonas species has been extensively studied, and potential applications have been proposed (Maier and Soberón-Chávez 2000). Rhamnolipids from Pseudomonas aeruginosa are currently commercialised by Jeneil Biosurfactant, USA, mainly as a fungicide for agricultural purposes or an additive to enhance bioremediation activities. Trehalolipids are produced by a number of different microorganisms, such as Mycobacterium, Nocardia and Corynebacterium. However, the most extensively studied compounds in this class are trehalose dimycolates produced by Rhodococcus erythropolis (Rapp et al. 1979). Sophorolipids, on the other hand, are produced mainly by yeasts, such as Candida bombicola (also known as Torulopsis bombicola), Centrolene petrophilum, Candida apicola and Rhodotorula bogoriensis, while MELs are produced by Pseudozyma yeasts, Pseudozyma aphidis, Pseudozyma antarctica and Pseudozyma rugulosa (Konishi et al. 2007a, b). Cyclic lipopeptides are produced by a number of Bacillus species as antibiotic molecules. Among these, the most important compound is surfactin produced by Bacillus subtilis because of its very high activity (Desai and Banat 1997; Rosenberg and Ron 1999). A wide variety of microorganisms, including some Archaea, produce high-molecular-weight polymers, the most extensively investigated being bioemulsans (Fig. 1) which are synthesised by various species of Acinetobacter. The first studied compound was RAG-1 emulsan, an amphiphilic polysaccharide produced by Acinetobacter calcoaceticus RAG-1, which is also the only commercially available bioemulsifier at present (Suthar et al. 2008).

\section{Potential applications}

\section{Environmental applications}

In many cases, environmental contamination caused by industrial activity is due to accidental or deliberate release of organic and/or inorganic compounds into the environment. Such compounds pose problems for remediation, as they become easily bound to soil particles. The application of biosurfactants in the remediation of organic compounds, such as hydrocarbons, aims at increasing their bioavailability (biosurfactant-enhanced bioremediation) or mobilising and removing the contaminants by pseudosolubilisation and emulsification in a washing treatment. The application of biosurfactants in the remediation of inorganic compounds such as heavy metals, on the other hand, is targeted at chelating and removal of such ions during a washing step facilitated by the chemical interactions between the amphiphiles and the metal ions.

\section{Biosurfactant-enhanced bioremediation}

Amphiphiles are able to alter the physico-chemical conditions at the interfaces affecting the distribution of the chemicals among the phases (Tiehm 1994). For instance, a hydrocarbon-contaminated soil contains at least six phases: bacteria, soil particles, water, air, immiscible liquid and solid hydrocarbon. The hydrocarbons can be partitioned among different states: solubilised in the water phase, ad/ absorbed to soil particle, sorbed to cell surfaces and as a free/insoluble phase. Biosurfactants added to this system can interact with both the abiotic particles and the bacterial cells.

This affects the mechanisms of interaction with environments with regard to the micellarisation and emulsification of organic contaminants, the interaction with sorbed contaminants and the sorption to soil particles which leads to the alteration of cell-envelope composition and hydrophobicity. The interactions between micelles and cells are among the main alterations to the bacterial component (Volkering et al. 1998). These phenomena on the one hand can be exploited to increase the bioavailability of poorly soluble contaminants, thus increasing biodegradation rate, or on the other hand, can result in an inhibition of biodegradation.

In spite of the publication bias which favours an overpublication of successful applications, the main emerging feature of the large body of literature in this area is the contrasting result reported on efficiency. For instance, rhamnolipids can stimulate the degradation of $n$-hexadecane by the producer strain $P$. aeruginosa, but didn't stimulate degradation by Rhodococcus strains showing strain specificity. In contrast, biosurfactants from $R$. erythropolis strain 3C-9 significantly increased the degradation rate of $n$-hexadecane by two phylogenetically distant species, Alcanivorax dieselolei and Psychrobacter celer, in flask tests (Noordman and Janssen 2002; Peng et al. 2007). Therefore, with the current state of knowledge, the modelling of the effect of biosurfactant addition in bioremediation treatment is not predictable, and efficacy has to be evaluated experimentally (Franzetti et al. 2006, 2008b). To gain better insight into this problem, it is useful to review the current knowledge and recent advances regarding these interactions.

For excellent reviews about interactions between surfactants and the environment, see Volkering et al. (1998) and Paria (2008). The interactions between bacteria, contaminants and biosurfactant can be interpreted from a functional perspective, considering that the main natural role attributed to biosurfactants is their involvement in hydrocarbon uptake (Perfumo et al. 2010a). Microbial surfactants can promote the growth of bacteria on hydrocarbons by increasing the surface area between oil and water and through emulsification and increasing pseudosolubility of 
hydrocarbons through partitioning into micelles (Miller and Zhang 1997; Volkering et al. 1998).

High-molecular-weight biosurfactants (bioemulsifiers) have great potential for stabilising emulsions between liquid hydrocarbons and water, thus increasing the surface area available for bacterial biodegradation. However, they have been rarely tested as enhancers of hydrocarbon biodegradation in bioremediation systems, and contrasting results are reported in the literature (Barkay et al. 1999; Franzetti et al. 2009a).

For low-molecular-weight biosurfactants, above the Critical Micelle Concentration (CMC), a significant fraction of the hydrophobic contaminant partitions in the surfactant micelle cores. In some cases, this results in a general increase in the bioavailability of contaminants for degrading microorganisms. Successful applications of rhamnolipids and surfactin in enhanced bioremediation have been recently reviewed (Mulligan 2009). In addition, Wang and Mulligan (2009) studied the effect of ammonium ion concentration and $\mathrm{pH}$ on the potential application of rhamnolipid and surfactin for enhanced biodegradation of diesel. A lipopeptide and protein-starch-lipid produced by two strains of $P$. aeruginosa significantly enhanced the solubilisation of phenanthrene, pyrene and fluorene, increasing their metabolism and supporting sustained growth (Bordoloi and Konwar 2009). Polycyclic Aromatic Hydrocarbons (PAH) biodegradation was also investigated by Das et al. (2008b); they used Bacillus circulans to increase the bioavailability of anthracene. Interestingly, the organism had better growth and biosurfactant production on glycerol containing mineral medium supplemented with anthracene, although it was unable to utilise anthracene as the sole carbon source. These authors were able to demonstrate, however, that anthracene was used as a substrate for the production of the biosurfactant.

The specific modes of hydrocarbon uptake, however, are not fully understood. Recently Cameotra and Singh (2009) elucidated the mechanism of $n$-hexadecane uptake mediated by rhamnolipids in $P$. aeruginosa. The rhamnolipids produced an emulsion with hexadecane, thus facilitating increased contact between the hydrocarbon substrate and the bacteria. It was also observed that uptake of the biosurfactant-coated hydrocarbon droplets occurred, suggesting a mechanism like pinocytosis taking place, a process not previously reported in bacterial hydrocarbon uptake systems.

In contrast, it is well known that the presence of a surfactant can detrimentally affect biodegradation. Micelle cores can trap organic contaminants, creating a barrier between microorganisms and organic molecules, resulting in the potential substrate becoming less rather than more available. For example, Witconol SN70, a non-ionic alcohol ethoxylate surfactant (Colores et al. 2000), reduced the biodegradation rate of hexadecane and phenanthrene, with biodegradation similarly inhibited by Tween 20 , sodium dodecyl sulfonate, tetradecyl trimethyl ammonium bromide and Citrikleen at concentrations equal or greater than their CMCs (Billingsley et al. 1999).

Another proposed role of biosurfactants in hydrocarbon uptake is the regulation of cell attachment to hydrophobic and hydrophilic surfaces by exposing different parts of cellbound biosurfactants, thus changing cell-surface hydrophobicity (Rosenberg et al. 1987; Franzetti et al. 2008a).

This natural role can be exploited by adding (bio) surfactants to increase the hydrophobicity of degrading microorganisms and to allow cells' easier access to hydrophobic substrates (Shreve et al. 1995). The release of LPS by Pseudomonas spp. induced by sub-CMC levels of rhamnolipids allowed a more efficient uptake of hexadecane by rendering the cell surface more hydrophobic (Al-Tahhan et al. 2000). Noordman and Janssen (2002) reported that rhamnolipid produced by $P$. aeruginosa UG2 facilitated the hydrocarbon uptake of the producer strain and increased the degradation of hexadecane, while the same product did not stimulate to the same extent the biodegradation of hexadecane by four unrelated species (Acinetobacter lwoffii RAG1, R. erythropolis ATCC 19558, R. erythropolis DSM 43066 and strain BCG112), nor was degradation of hexadecane stimulated by addition of the biosurfactants produced by these species themselves. Zhong et al. (2007) showed that the adsorption of dirhamnolipid biosurfactants on cells of B. subtilis, $P$. aeruginosa and Candida lipolytica depended on the physiological status of the cells and was specific to the microorganisms. Furthermore, the biosurfactant adsorption affected the cell-surface hydrophobicity depending on the rhamnolipid concentration and the physiological state of the cell. The effect of exogenous rhamnolipids on cell-surface composition of $P$. aeruginosa NBIMCC 1390 was recently studied by Sotirova et al. 2008. They showed that above the CMC, rhamnolipids caused a $22 \%$ reduction of total cellular LPS content, while at concentrations below the CMC, they caused changes in the bacterial outer membrane protein composition yet did not affect the LPS component.

Chang et al. (2009) demonstrated that the cell-surface hydrophobicity was enhanced by the accumulation at the cell surface of different fatty acids during growth on hydrocarbon in $R$. erythropolis NTU-1. A significant correlation between the modification of the cell surface by saponins and the degree of hydrocarbon biodegradation was reported by Kaczorek et al. (2008).

\section{Biosurfactant-enhanced soil washing}

The application of microbial SACs to remove contaminants from soils is a technology characterised by less 
uncertainty than biosurfactant-enhanced bioremediation, since the removal efficiency is mainly driven by the chemico-physical properties of the biosurfactants and not their effect on metabolic activity or changes in cell-surface properties. However, the mechanisms affecting hydrocarbon mobilisation or removal from soils resemble those involved in enhancing bioavailability for bioremediation. The ability to stabilise oil/water emulsions and increase hydrocarbon solubility enhances biodegradation and hydrocarbon removal from soils (Franzetti et al. 2010). These mobilisation and solubilisation effects occur at concentrations above and below the CMC. Mulligan (2009) reviewed the application of biosurfactants in enhanced soil washing for hydrocarbon- and metal-contaminated soils. More recently, Franzetti et al. (2009b) reported efficient removal of crude oil from soil using extracellular bioemulsifier produced by Gordonia sp. BS29. Interesting papers reporting enhanced metal removal or mobilisation have been published in the past 2 years. Biosurfactants are efficient in removing bulk arsenic from mine tailings or contaminated soils under alkaline conditions (Wang and Mulligan 2009). Das et al. (2009) showed that cadmium removal from aqueous solution also occurred at concentrations less than the $\mathrm{CMC}$, while at a concentration of five times, the CMC resulted in almost complete removal of $100 \mathrm{ppm}$ of metal ions. Wen et al. (2009) studied rhamnolipid degradation in soils contaminated by $\mathrm{Cd}$ and $\mathrm{Zn}$, they suggested that rhamnolipid in the soil remain long enough to enhance metal phytoextraction, yet not long enough to raise concerns regarding metal transport in the long term.

\section{Industrial applications}

The main industrial application for biosurfactants is in the field of oil recovery and processing. Since traditional oil recovery technologies can only recover approximately 40 $45 \%$ of the oil present in the reservoir, some technologies, collectively defined as enhanced oil recovery (EOR), have been developed (Banat 1995; Dastgheib et al. 2008). Among these, microbial EOR (MEOR), which takes advantage of microbial production of surface-active compounds, is considered to have the most cost-effective potential (Sen 2008). When poor oil recovery from oil wells is due to either low permeability of the rocks forming the reservoir or to the high viscosity of the crude oil, the ability of biosurfactants to reduce the oil/water interfacial tension and to form stable emulsions can improve the process efficiency. Three different strategies have been identified for MEOR: biosurfactant production in offsite reactors and subsequent addition to the oil reservoir; biosurfactant production by injected allochthonous microorganisms; injection of nutrients into the reservoir to stimulate biosurfactant production in situ by indigenous bacteria (Singh et al. 2007).

At present, the first strategy is the most exploited. In practice, a major obstacle to the in situ production of biosurfactants is the difficulty of isolating microbial strains adapted to the extreme environment of the reservoirs, which features high pressure, salinity, temperatures up to $85^{\circ} \mathrm{C}$ and extreme $\mathrm{pH}$ values. All the main types of microbial surface-active compounds have been proposed for a MEOR application. Although rhamnolipids have been most frequently used, lipopeptides, such as surfactin, lichenysin and emulsan have also proved very effective in enhancing oil recovery (Sen 2008). Xu et al. (2009) further demonstrated the effectiveness of a polysaccharide produced by Streptococcus sp. BT-003 for the same application. The use of biosurfactants in MEOR has been extensively reviewed (Banat et al. 2000; Singh et al. 2007; Sen 2008). Recently, several laboratory experiments were carried out to evaluate the effectiveness of biosurfactant-assisted oil extraction and recovery. Biosurfactants produced by $R$. erythropolis and Rhodococcus ruber were used to extract hydrocarbons from oil shale in flask experiments; the maximum recovery was $25 \%$ and $26 \%$ for the two strains, respectively, with even lower recovery when a high percentage of asphaltenes and resin compounds were present in the oil (Haddadin et al. 2009).

When the main purpose of the laboratory evaluation is a screening to test candidate molecules for full-scale application, most experiments are currently performed in sandpacked column systems to simulate oil reservoir conditions. Pornsunthorntawee et al. (2008) demonstrated that both $B$. subtilis PT2 and P. aeruginosa SP4 biosurfactants were more effective than three synthetic surfactants in oil recovery from a sand-packed column, the $B$. subtilis product being the most effective with an oil removal of $61 \%$ against $57 \%$ for the $P$. aeruginosa surfactants and about 4\% when distilled water was used. Some other microbial surface-active compounds were also tested in column systems. For example, a bioemulsifier from Bacillus licheniformis $\mathrm{K} 125$, which reduced the surface tension to $34 \mathrm{mN} / \mathrm{m}$, gave about $43 \%$ additional oil recovery after water extraction (Suthar et al. 2008), while some biosurfactants from different strains of $P$. aeruginosa gave 49-62\% oil recovery (Bordoloi and Konwar 2008).

Although offsite biosurfactant production is the most common practice in MEOR, its potential has not been fully realised yet due to its high cost. To reduce costs, Wang et al. (2007) suggested selecting Pseudomonas strains, which can efficiently grow on renewable low-cost substrates and genetically engineer them to produce high yields of rhamnolipid. The prospect for such a strategy is probably quite poor since the production of rhamnolipids in Pseudomonas regulated through the quorum sensing 
system and genetic intervention is difficult. However, an alternative would be an in situ production of biosurfactants, either by injected bacteria or by stimulated autochthonous microorganisms. Therefore some effort has recently been put into isolating new surfactant-producing microbial strains using extreme conditions to reproduce those encountered in oil reservoirs (Agarwal and Sharma 2009), while other research has focused on selective activation of indigenous microorganisms able to enhance oil recovery (Bao et al. 2009). The potential utilisation of selected exogenous microoganisms can be assessed either in the laboratory or directly in the field. The performance of two bacteria, B. subtilis and Leuconostoc mesenteroides, biosurfactant- and exopolymer-producing strains, respectively, were evaluated by using oil-saturated glass micromodels of a fractured porous medium to determine oil recovery. B. subtilis gave better oil recovery due to the reduction of oil viscosity and the interfacial tension (Soudmand-Asli et al. 2007).

While a number of field trials of in situ applications of MEOR are reported in the literature (see Sen 2008 for a review), it has not been completely elucidated whether introduced microorganisms can actually be effective in oil recovery or if they are out-competed by indigenous bacteria. The inability to compare test wells with control wells subjected to similar treatment procedures without introducing live microorganisms or products makes valid conclusions difficult to draw. To provide better insight into the dynamics of the microbial community, Wang et al. (2008) monitored changes in the community using molecular markers by denaturing gradient gel electrophoresis in an oil reservoir during a process of MEOR. They observed that both exogenous and stimulated indigenous bacteria appeared to contribute to the increased oil recovery.

Beside applications in MEOR, microbial surface-active compounds can also be exploited for other applications in the oil industry. For example, the de-emulsifying properties shown by some biosurfactant-producing microorganisms may be used to break emulsions which form at various steps in oil extraction and processing, thus allowing a better recovery of the product. The surfacetension decrease produced by microbial surfactants can also be used to separate oil from tank bottom sludge (Singh et al. 2007; Joseph and Joseph 2009; Perfumo et al. 2010b).

Due to their physico-chemical properties, the use of microbial surface-active compounds has also been proposed for various industrial applications, as additives in foods, cosmetics and detergent formulations (Banat et al. 2000). In the food industry, the most useful property is the ability to form stable emulsions, which improves the texture and creaminess of dairy products. Biosurfactants are also used to retard staling, solubilise flavour oils and improve organoleptic properties in bakery and ice cream formulations and as fat stabilisers during cooking of fats. Although the addition of rhamnolipids has been suggested to improve dough characteristics of bakery products, the use as food ingredients of compounds derived from an opportunistic pathogen such as $P$. aeruginosa is not practically feasible. Instead, it has been suggested to use biosurfactants obtained from yeasts or Lactobacilli, which are generally recognised as safe and are already involved in several food-processing technologies (Nitschke and Costa 2007).

Wetting, dispersing and surface-tension reduction properties, as well as low toxicity and high biodegradability, suggested the application of biosurfactants, especially glycolipids, as components of detergent formulations. Low-foaming sophorolipids from C. bombicola appear suitable due to their high detergency ability, low cytotoxicity and high biodegradability and general environmentally acceptable properties (Hirata et al. 2009). Also, cyclic lipopeptide biosurfactants from $B$. subtilis improved wash performance by acting additively with other detergent components. Since they have shown better results at low temperature, such formulations are promising from an energy-saving point of view, allowing laundering at lower temperatures (Mukherjee 2007). Several surfactant-enzyme mixtures were tested for rubisco removal from both hydrophobic and hydrophilic surfaces; the most effective formulation was a surfactin-subtilisin A detergent, thus demonstrating that it would be possible to generate fully renewable cleaning formulations with good performance (Onaizi et al. 2009).

\section{Biomedical applications}

Biosurfactants, when present in heterogeneous systems, tend to aggregate at the phase boundaries or interfaces. Organic molecules present in aqueous phase are known to be inclined to immobilise at the solid interface is such interfacial systems. They eventually form a conditioning film, which will affect the properties (surface energy and wettability) of the original surface (Neu 1996). In a similar manner to organic-conditioning films, biosurfactants partition at the interfaces and can affect the adhesion properties of microorganisms. Another function valuable for medical application is their ability to disrupt membranes leading to cell lysis through increased membrane permeability leading to metabolite leakage. This occurs due to changes in physical membrane structure or through disrupting protein conformations which alters important membrane functions such as transport and energy generation (Van Hamme et al. 2006; Ortiz et al. 2008, 2009; Sotirova et al. 2008; Sánchez et al. 2009, 2010; Zaragoza et al. 2009). 


\section{Antimicrobial activity of biosurfactants}

The high demand for new antimicrobial agents following increased resistance shown by pathogenic microorganisms against existing antimicrobial drugs has drawn attention to biosurfactants as antibacterial agents (Bĕhal 2006). Some biosurfactants have been reported to be suitable alternatives to synthetic medicines and antimicrobial agents and may therefore be used as effective and safe therapeutic agents (Cameotra and Makkar 2004; Singh and Cameotra 2004; Banat et al. 2000).

Lipopeptides form the most widely reported class of biosurfactants with antimicrobial activity. Surfactin, produced by B. subtilis, is the best-known lipopeptide (Arima et al. 1968). Other antimicrobial lipopeptides include fengycin, iturin, bacillomycins and mycosubtilins produced by B. subtilis (Vater et al. 2002). Lichenysin, pumilacidin and polymyxin B (Naruse et al. 1990; Yakimov et al. 1995; Grangemard et al. 2001; Landman et al. 2008) are other antimicrobial lipopeptides produced by $B$. licheniformis, Bacillus pumilus and Bacillus polymyxa, respectively. The production of antimicrobial lipopeptides by Bacillus probiotic products is one of the main mechanisms by which they inhibit the growth of pathogenic microorganisms in the gastrointestinal tract (Hong et al. 2005). Other reported biosurfactants having antimicrobial activity are daptomycin, a cyclic lipopeptide from Streptomyces roseosporus (Baltz et al. 2005), viscosin, a cyclic lipopeptide from Pseudomonas (Neu et al. 1990; Saini et al. 2008), rhamnolipids produced by P. aeruginosa (Abalos et al. 2001; Benincasa et al. 2004) and sophorolipids produced by $C$. bombicola (Kim et al. 2002; Van Bogaert et al. 2007). Mannosylerythritol lipids (MEL-A and MEL-B) produced by Candida antarctica strains have also been reported to exhibit antimicrobial action against Gram-positive bacteria (Kitamoto et al. 1993).

Recently, a lipopeptide biosurfactant produced by a marine organism, B. circulans, was found to be active against Proteus vulgaris, Alcaligens faecalis, methicillinresistant Staphylococcus aureus (MRSA) and other multidrug-resistant pathogenic strains (Das et al. 2008a) while not having any haemolytic activity. A rhamnolipid surfactant produced from soybean oil waste had antimicrobial activity against several bacteria and fungi, namely Bacillus cereus, S. aureus, Micrococcus luteus, Mucor miehei and Neurospora crassa (Nitschke et al. 2009b). Flocculosin, a cellobiose lipid produced by the yeast-like fungus Pseudozyma flocculosa, was tested against clinical bacterial isolates and the pathogenic yeast Candida albicans (Mimee et al. 2009). The glycolipid was particularly effective against Staphylococcus species, including MRSA, and its antibacterial activity was not influenced by the presence of common resistance mechanisms (e.g. against methicillin and vancomycin) in tested strains. In addition, flocculosin was able to kill $C$. albicans cells in a very short period of time. Huang et al. (2007) observed that a lipopeptide antimicrobial substance produced by the strain $B$. subtilis fmbj, which is mainly composed of surfactin and fengycin, was able to inactivate endospores of $B$. cereus. Observation by TEM indicated that the lipopeptide could damage the surface structure of the spores.

Antiviral activity of biosurfactants, mainly surfactin and its analogues, has also been described (Naruse et al. 1990). The more effective inactivation of enveloped viruses, such as retroviruses and herpes viruses, compared to non-enveloped viruses, suggests that this inhibitory action may be mainly due to physico-chemical interactions between the virus envelope and the surfactant (Vollenbroich et al. 1997). Antimicrobial lipopeptides produced by $B$. subtilis fmbj inactivated cell-free virus of porcine parvovirus, pseudorabies virus, newcastle disease virus and bursal disease virus, while it effectively inhibited replication and infectivity of the newcastle disease virus and bursal disease virus but had no effect on pseudorabies virus and porcine parvovirus (Huang et al. 2006). Sophorolipids are also claimed to have activity against human immunodeficiency virus (Shah et al. 2005). Similarly, a rhamonolipid and its complex with alginate, both produced by a Pseudomonas sp. strain, showed significant antiviral activity against herpes simplex virus types 1 and 2 (Remichkova et al. 2008). The suppressive effect of the compounds on herpes simplex virus replication was dose-dependent and occurred at concentrations lower than the critical micelle concentration.

The antifungal activities of biosurfactants have long been known, although their action against human pathogenic fungi has been rarely described (Tanaka et al. 1997; Chung et al. 2000; Abalos et al. 2001). Recently, a glycolipid isolated from the yeast-like fungus $P$. flocculosa, named flocculosin was shown to display in vitro antifungal activity against several pathogenic yeasts, associated with human mycoses (Mimee et al. 2005). This product positively inhibited all pathogenic strains tested under acidic conditions and showed synergistic activity with amphotericin $\mathrm{B}$, increasing its efficacy while decreasing any toxicity and other side effects.

The antifungal activity against phytopathogenic fungi has been demonstrated for glycolipids, such as cellobiose lipids (Teichmann et al. 2007; Kulakovskaya et al. 2009, 2010) and rhamnolipids (Debode et al. 2007; Varnier et al. 2009), and cyclic lipopeptides (Tran et al. 2007, 2008), including surfactin, iturin and fengycin (Velmurugan et al. 2009; Arguelles-Arias et al. 2009; Chen et al. 2009; Snook et al. 2009; Mohammadipour et al. 2009; Grover et al. 2010). 


\section{Biosurfactants as anti-adhesives}

Biofilm formation and swarming motility are the key microbial activities in the colonisation of a surface and therefore can increase the chance of nosocomial infections on different medical devices (Khardori and Yassien 1995; Vinh and Embil 2005; McCann et al. 2008; Harriott and Noverr 2009). Current biofilm preventive strategies are essentially aimed at coating medical surfaces with antimicrobial agents (von Eiff et al. 2005; Basak et al. 2009). However, recent studies have suggested that non-antibiotic molecules naturally produced within bacterial communities, including secreted signalling molecules or surface-active biosurfactants, could also interfere with biofilm formation, modulating microbial interaction with interfaces (Neu 1996; Federle and Bassler 2003; Rasmussen and Givskov 2006; Rodrigues et al. 2006a). In addition to their direct action against pathogens, biosurfactants can also alter the physical and chemical condition of the environment where biofilms are developing (Mireles et al. 2001; Merk et al. 2005). Dealing with these biofilms is difficult yet an important goal, since microbes embedded within them are associated with many infections and usually become difficult to treat effectively with traditional antimicrobials (Morikawa 2006).

Recently, the capability of two lipopeptide biosurfactants, produced by B. subtilis V9T14 and B. licheniformis V19T21, to inhibit biofilm adhesion of pathogenic bacteria to polystyrene was demonstrated using the MBEC device (Rivardo et al. 2009). The two biosurfactants V9T14 and V19T21 showed interesting specific anti-adhesion activity being able to selectively inhibit biofilm formation by two pathogenic strains. In particular, S. aureus ATCC 29213 and Escherichia coli CFT073 biofilm formation were decreased by $97 \%$ and 90\%, respectively. V9T14 biosurfactant active on the Gram-negative strain was ineffective against the Gram-positive and the opposite for V19T21 biosurfactant. This activity was observed either by coating the polystyrene surface or by adding the biosurfactant to the inoculum.

Two fractions from each purified biosurfactant, obtained by flash chromatography, fractions (I) (surfactin) and (II) (fengycin), showed that fraction (II) was responsible for the anti-adhesion activity in both strains. Moreover the V9T14 biosurfactant has been shown to increase biofilm eradication efficacy of different antibiotics against a urinary tractinfective E. coli strain (Martinotti et al. 2009-deposited patent). More recently, the activity of $\mathrm{AgNO}_{3}$ combined with the lipopeptide biosurfactant V9T14 has been studied against a preformed E. coli biofilm on the Calgary Biofilm device (Rivardo et al. 2010). Results indicated that the activity of silver can be synergistically enhanced by the presence of V9T14, allowing a reduction in the quantity of silver used and greater antimicrobial activity. The concentration of silver in the silver-biosurfactant solution was from 129- to 258-fold less than the concentration when silver was used alone. Based on these results, an international patent PCT/IB2009/055334 entitled "Biosurfactant composition produced by a new $B$. licheniformis strain, uses and products thereof" has been deposited in 2009, inventors Martinotti M.G., Rivardo F. Allegrone G., Ceri H., Turner R. Unpublished preliminary results obtained by the same research group showed anti-adhesion effects of two lipopeptides produced by bacterial endophytes, isolated from oleander and rice, on the biofilm of two different pathogenic strains of $C$. albicans (Fig. 2).

Valle et al. (2006) observed that distinct serotypes of group II capsular polysaccharides, produced by the uropathogenic E. coli (UPEC strain CFT073) behaved like surface-active polymers that displayed anti-adhesion properties. The treatment of abiotic surfaces with group II capsular polysaccharides significantly inhibit mature biofilm development of a broad range of Gram-positive and Gram-negative bacteria.

Strategies for the prevention of microbial biofilm formation on silicone rubber voice prostheses on vinyl urethral catheters and on other material have also been described (Velraeds et al. 2000; Mireles et al. 2001; Rodrigues et al. 2004, 2006b, c, 2007).

Beside treatment of medical devices, biosurfactants have been used in the pre-treatment of material surfaces found in food-processing environments. Listeria monocytogenes, Salmonella enteritidis and Enterobacter sakazakii are examples of pathogenic bacteria implicated in outbreaks associated with the ingestion of contaminated food. Numerous studies have shown that these bacteria are able to adhere and to form biofilms on food-contact surfaces that are more resistant to sanitation than free-living cells (Kalmokoff et al. 2001; Stepanovic et al. 2004; Kim et al. 2006). The pre-conditioning of surfaces using microbial surface-active compounds could be an interesting strategy to prevent adhesion of food-borne pathogens to solid surfaces.

Meylheuc et al. (2006b) demonstrated that the preconditioning of stainless steel and polytetrafluoroethylene surfaces with an anionic biosurfactant produced by $\mathrm{Pseu}$ domonas fluorescens reduced the number of $L$. monocytogenes LO28-adhering cells and thus resembled the bactericidal activities of the disinfectants sodium hypochlorite $(\mathrm{NaOCl})$ and peracetic acid/hydrogen peroxide $(\mathrm{PAH})$. Similarly, the ability of adsorbed biosurfactants obtained from Lactobacillus helveticus and P. fluorescens to inhibit the adhesion of four Listeria strains to stainless steel was investigated (Meylheuc et al. 2006a). Whichever strain of L. monocytogenes used in combination with biosurfactants, the anti-adhesive biological coating developed both reduced 
Fig. 2 Anti-adhesion activity of biosurfactants OC5 and RA1 produced by two bacterial endophytes against biofilm produced by $C$. albicans strains. Shaded columns, untreated controls; white columns, treatments with different biosurfactants concentrations. Vertical bars show the standard deviation of the mean based on three independent measurements. ${ }^{*} P<$ 0.05 calculated by $t$ test

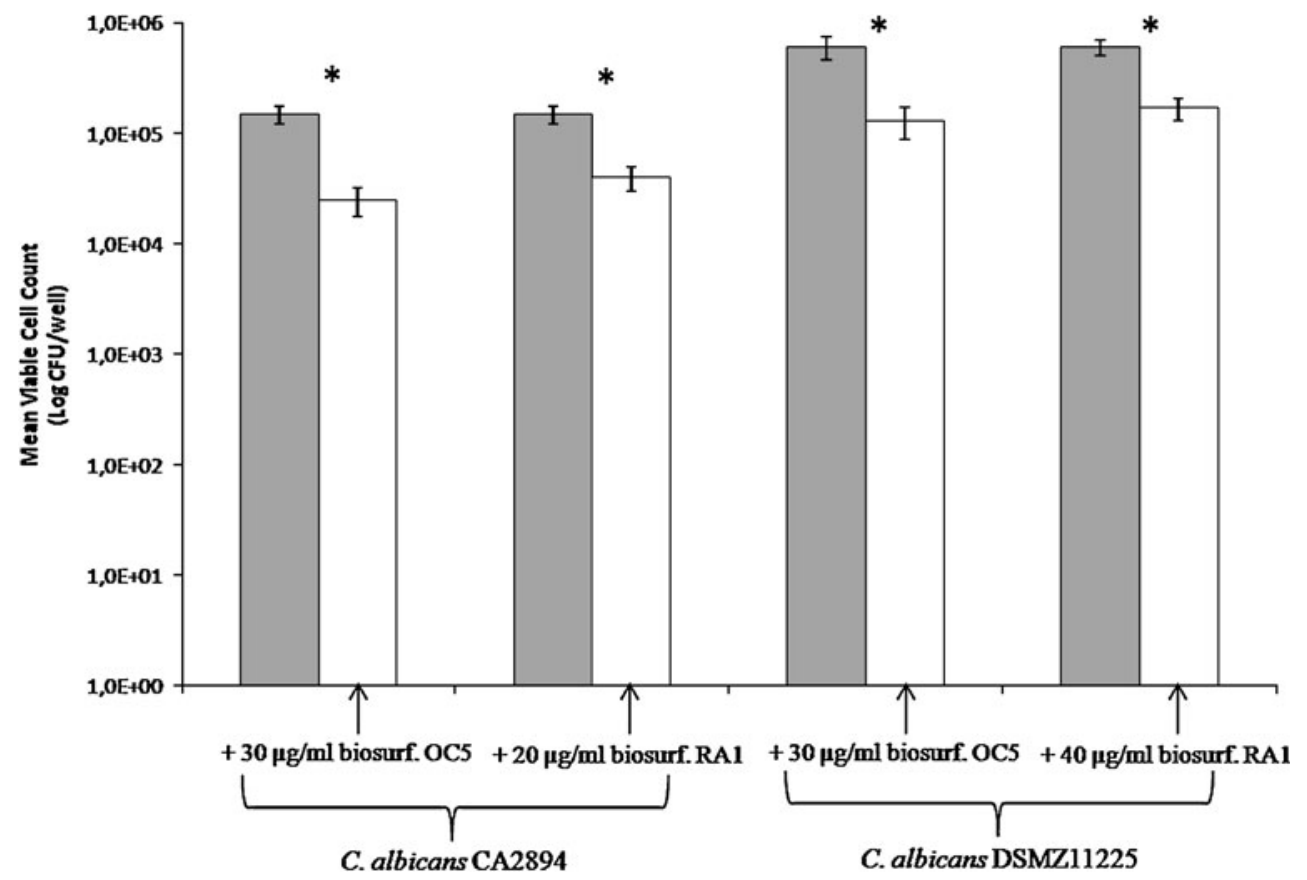

the total adhering flora and the viable and culturable adherent bacteria on stainless steel surfaces. More recently, another group investigated the effect of rhamnolipids and surfactin biosurfactants on the adhesion of the food pathogens E. sakazakii, L. monocytogenes and S. enteritidis to polypropylene and stainless steel surfaces (Nitschke et al. 2009a). Preconditioning with surfactin, rather than rhamnolipid, caused a reduction in the number of adhering cells particularly of $L$. monocytogenes and to some extent $E$. sakazakii on stainless steel. Surfactin showed a significant decrease in the adhesion on polypropylene of all strains. The adsorption of surfactin on polystyrene also reduced the adhesion of $S$. enteritidis- and L. monocytogenes-growing cells. In addition, surfactin was able to delay bacterial adhesion within short contact periods using non-growing cells or longer contact periods using growing cells.

Probiotics have long been known for their antimicrobial activity and for the capacity to interfere with the adhesion and formation of biofilms of pathogens to epithelial cells of urogenital and intestinal tracts (Reid et al. 1998, 2001), catheter materials (Hawthorn and Reid 1990) and voice prostheses (Rodrigues et al. 2004, 2006b), and the mechanisms of this interference have been demonstrated to include, among others, the release of biosurfactants (Velraeds et al. 1996; Rodrigues et al. 2006d; Gudiña et al. 2010). Probiotics are thus well known to have a positive effect on the maintenance of human health (Reid and Burton 2002; Merk et al. 2005; Gupta and Garg 2009).

Recent work by Walencka et al. (2008) demonstrated that surfactants obtained from three Lactobacillus acidophilus strains inhibited Staphylococcus epidermidis and $S$. aureus biofilm integrity and formation. Moreover, surfactant addition to preformed mature biofilms accelerated their dispersal and altered the characteristics of the biofilm morphology.

Another interesting application field for probiotics that is gaining more interest is their use in preventing oral infections. The role of probiotics on oral health has been thoroughly investigated (Çaglar et al. 2005; Meurman 2005; Meurman and Stamatova 2007; Hatakka et al. 2007; Kõll et al. 2008). Van Hoogmoed et al. (2004) demonstrated that Streptococcus mitis biosurfactant inhibited adhesion of Streptococcus sobrinus HG 1025 and Streptococcus mutans ATCC 25175 to bare enamel, while $S$. mitis biosurfactant was able to inhibit the adhesion of $S$. sobrinus HG 1025 to salivary pellicles. The authors later reported that these reductions may be attributed to increased electrostatic repulsion between the bacteria and the biosurfactant-coated pellicles (Van Hoogmoed et al. 2006).

\section{Other biomedical and therapeutic applications}

Biosurfactants have been shown to have many other roles in biomedical application. Surfactin is one of the most powerful biosurfactants and is known to have anti-inflammatory, antibiotic and anti-tumour functions (Seydlová and Svobodová 2008). Cao et al. (2010) demonstrated that surfactin induces apoptosis in human breast cancer MCF-7 cells through a ROS/JNK-mediated mitochondrial/caspase pathway, whereas Byeon et al. (2008) observed that surfactin was able to downregulate LPS-induced NO production in RAW264.7 cells and 
primary macrophages by inhibiting NF- $\mathrm{kB}$ activation. Park and Kim (2009) studied the role of surfactin in the inhibition of the immunostimulatory function of macrophages through blocking the NK-KB, MAPK and Akt pathway. This provided a new insight into the immunopharmacological role of surfactin in autoimmune disease and transplantation. Their work indicated that surfactin has potent immunosuppressive capabilities which suggested important therapeutic implications for transplantation and autoimmune diseases, including allergy, arthritis and diabetes.

Selvam et al. (2009) studied the effect of B. subtilis PB6, a natural probiotic, on plasma cytokine levels in inflammatory bowel disease and colon mucosal inflammation. The strain was found to secrete surfactins which are known to inhibit phospholipase A2, involved in the pathophysiology of inflammatory bowel disease. In animal experiments carried out in rat models for trinitrobenzene sulfonic acidinduced colitis, oral administration of PB6 as a probiotic suppressed colitis as measured by mortality rate and changes in colon morphology and weight gain. Plasma levels of pro-inflammatory cytokines were also significantly lowered and the anti-inflammatory cytokine significantly increased after the oral administration of PB6, supporting the concept that PB6 inhibits PLA2 by secreting surfactins. Han et al. 2008 observed that high surfactin micelle concentration affected the aggregation of amyloid $\beta$-peptide (A $\beta$ (1-40)) into fibrils, a key pathological process associated with Alzheimer's disease. Another interesting property of surfactin and its synthetic analogues is the ability to alter the nanoscale organisation of supported bilayers and to induce nanoripple structures with intriguing perspectives for biomedical and biotechnological applications (Bouffioux et al. 2007; Brasseur et al. 2007; Francius et al. 2008). Fengycin, another lipopeptide biosurfactant is also able to cause membrane perturbations (Deleu et al. 2008). Recent results by Eeman et al. (2009) emphasised the ability of fengycin to interact with the lipid constituents of the stratum corneum extracellular matrix and with cholesterol.

The biological activities and the numerous potential applications of mannosylerythritol lipids (MELs), one of the most promising glycolipid biosurfactants produced by yeast strains of the genus Pseudozyma, have been thoroughly discussed by Kitamoto et al. (2009). Imura et al. (2007) and (2008), Ito et al. (2007) and Konishi et al. (2007a) developed and studied the kinetics of interactions in carbohydrate ligand systems composed of self-assembled monolayers of mannosylerythritol lipid-A (MEL-A) from $P$. antarctica serving as a high-affinity, easy to handle and low-cost ligand system for immunoglobulin $\mathrm{G}$ and $\mathrm{M}$ and lectins. Igarashi et al. (2006) reported that MEL-A significantly increased the cellular association and the efficiency of gene transfection mediated by cationic lip- osomes. Their results suggested that MEL-A enhanced the association of lipoplexes with the cells, delivered them widely into the cytoplasm and increased gene expression. Ueno et al. (2007a) observed that MEL-A-containing liposomes exhibited high activity in DNA capsulation and membrane fusion with anionic liposomes, which are important properties for gene transfection. On the other hand, MEL-B- and MEL-C-containing liposomes only increased either the capsulation or the membrane fusion. In another work, Ueno et al. (2007b) suggested that MEL-A was capable of increasing and rapidly promoting the transfection efficiency of target cells by inducing membrane fusion between liposomes and the plasma membrane of these cells.

In another work, a liposome vector containing betasitosterol beta-D-glucoside biosurfactant-complexed DNA was successfully used for herpes simplex virus thymidine kinase gene therapy (Maitani et al. 2006). More recently, nano-vectors containing a biosurfactant have been successfully used to increase the efficacy for gene transfection in vitro and in vivo (Nakanishi et al. 2009). On the other hand, Morita et al. (2009), using a three-dimensional cultured human skin model, observed that the viability of the SDSdamaged cells was markedly improved by the addition of MEL-A in a dose-dependent manner. This demonstrated that MEL-A had a ceramide-like moisturising activity toward the skin cells.

Another interesting application for natural surfactant is the possibility to synthesise metal-bound nanoparticles using an environmentally friendly technology benign (Palanisamy and Raichur 2009). The use of gold nanoparticles, in particular, is currently undergoing a dramatic expansion in the field of drug and gene delivery, targeted therapy and imaging (Pissuwan et al. 2009; Boisselier and Astruc 2009). Recently, Reddy et al. (2009) synthesised, for the first time, surfactin-mediated gold nanoparticles, opening the way to a new and fascinating application of biosurfactants in the biomedical field. Most recently Smyth et al. (2010c) reported on the production of selectively deuterated rhamnolipids and sophorolipids using deuterated substrates. The production of such deuterated biosurfactants in particular or other bioactive microbial products in general in which distinct pattern of labelling could be achieved would have great future implications with regards to efficacy and/or persistence or the development of resistance for some bioactives particularly in biomedical related applications.

\section{Production and optimisation}

Despite their environmentally favourable characteristics of higher biodegradability, lower toxicity, better foaming 
properties compared to their synthetic chemical counterparts while also showing better stability at extreme $\mathrm{pH}$, salinity and temperature, the commercialisation of microbial surfactants has not been fully achieved largely due to production costs. At present, the production costs for most biosurfactants do not compete with those of chemical surfactants. Different strategies have been proposed to make the process more cost effective including: (1) development of more efficient bioprocesses, including optimisation of fermentative conditions and downstream recovery processes, (2) use of cheap and waste substrates (Thavasi et al. 2007, 2008; Raza et al. 2009), (3) development of overproducing strains (Fig. 3). The increasing number of reports of potential antimicrobial and antiadhesive properties of biosurfactants against pathogenic microorganisms (Rodrigues et al. 2006a) has added to the impetus towards sustainability and reduced carbon foot prints (the greening process) which are helping drive the market towards efficient large-scale production technologies. However, most biosurfactant research related to largescale economic production trials has been mainly confined to microorganisms, such as Pseudomonas, Bacillus and Candida (Mukherjee et al. 2006).

Several developments in optimisation of culture conditions and downstream processing have been published recently. The use of agroindustrial by-products has been reported both for yeasts and bacteria (Makkar and Cameotra 2002). Sobrinho et al. (2008) used ground nut oil refinery residues and corn steep liquor as substrates for anionic glycolipid production by Candida spherical, while the biosynthesis of glycolipids by P. aeruginosa was obtained using cashew apple juice as substrate (Rocha et al. 2007) and vegetable oil refinery wastes (Raza et al. 2007). Very high potential for large-scale industrial application was achieved using the already commercialised Pharmamedia medium for surfactin production by B. subtilis MZ-7 (AlAjiani et al. 2007). The use of substrates such as soapstick, frying oil and motor oil have all been explored and have had limited success due to the need for more costly or demanding downstream processing. Novel strains able to produce biosurfactants on renewable and low-cost substrates have also been reported during the past few years. Ruggeri et al. (2009) isolated Rhodococcus sp. BS32 able to grow on rapeseed oil for the production of extracellular biosurfactants. Glycerol, however, has emerged as one important potential feedstock available in large quantities as a by-product of the biodiesel process (Zheng et al. 2008).

Experimental design techniques have been extensively used to optimise biosurfactant production. The use of surface response methodology effectively enhanced the production of biosurfactant by Rhodococcus spp. MTCC 2574 growing on $n$-hexadecane with yields of biosurfactant increasing from 3.2 to $10.9 \mathrm{~g} / \mathrm{L}$ (Mutalik et al. 2008). Working with Gordonia sp. BS29, Franzetti et al. (2009a) increased the production of cell-bound glycolipids by 5fold using surface response methodology, while the use of an artificial neutral network coupled with a genetic algorithm gave a 3.5-fold enhancement in biosurfactant yield (Pal et al. 2009). The same methodologies were applied by Sivapathasekaran et al. (2010) aimed at optimising biosurfactant production by $B$. circulans MTCC 8281. Kronemberger et al. (2008) reported a significant increase in yield by optimising cultural conditions using statistical tools. They also reported that the yields may be further enhanced by the development of new controlling devices such as oxygen control.

Downstream processing accounts for most of the total cost of a biotechnology product (Mukherjee et al. 2006). The most common isolation techniques for biosurfactants use precipitation, solvent extraction and chromatographic purification. Extraction of low-molecular-weight biosurfactant normally involves an optional precipitation step and the use of different organic solvents according to hydrophobicity and Hydrophilic-Lipophilic Balance (HLB) value of the compounds. Rhamnolipids are usually precipitated by acidification and extracted using ethyl acetate; extraction of sophorolipids is normally carried out
Fig. 3 Different cost-reduction strategies for production of microbial surface-active compounds

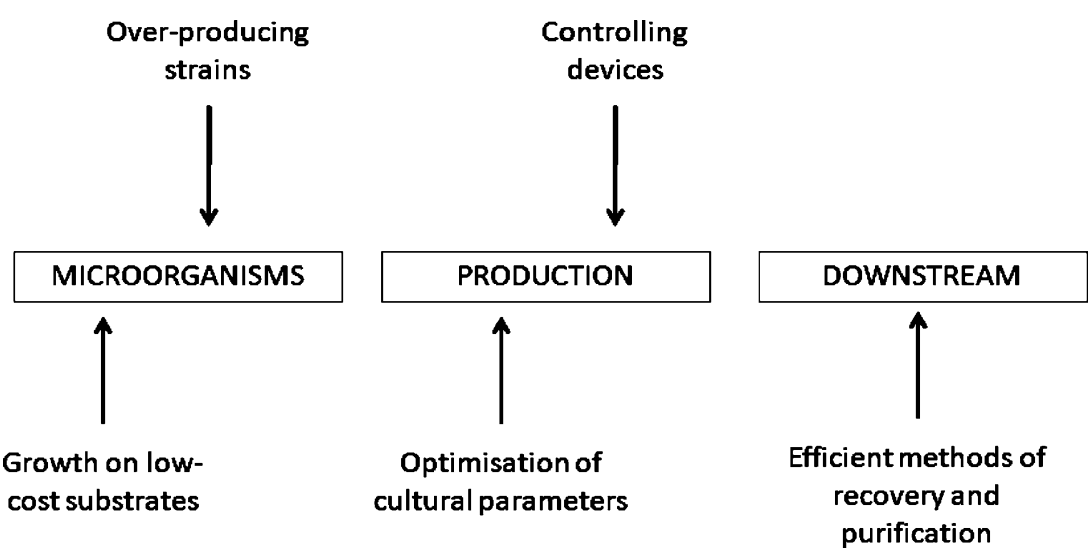


with $n$-hexane, while for trehalolipids, the preferred solvent is a mixture of chloroform and methanol. Methanol is also used as a solvent for extraction of lipopeptides after a precipitation by acidification (Smyth et al. 2010a). High-molecular-weight biosurfactants are usually extracted from the culture broth by ammonium sulphate precipitation and purified by dialysis. Other techniques for high-molecular-weight biosurfactant isolation are TCA/acetone precipitation, acid ethanol and chloroform/methanol (Smyth et al. 2010b). These techniques are already well established for lab-scale applications, but their cost does not allow scaling-up for industrial production of biosurfactants. For these reasons, the research effort is now directed towards the development of low-cost extraction and purification procedures, avoiding the use of hazardous and costly organic solvents.

Many advances have been observed in very recent years for recovery and purification of lipopeptides (Smyth et al. 2010a, b). Sivapathasekaran et al. (2009) developed and optimised an efficient method for the separation and purification of fengycin isoforms using high-performance liquid chromatography through manipulating the solvent gradient program and flow rates. Fengycin separation and purification was also obtained directly from the cultivation step without the use of solvent and foam formation by pressing and harvesting the liquid surface layer (Glazyrina et al. 2008). Dimitrov et al. (2008) applied liquid membrane extraction processes for recovery of surfactin, achieving $97 \%$ efficiency under optimised conditions. Chen and colleagues, in three different papers (Chen et al. 2008a, b; Chen and Juang 2008), optimised the recovery of surfactin from fermentation broths of B. subtilis ATCC 21332 by different methods and achieved improved purity by adsorption or ion exchange after the broth had been treated by a two-stage ultrafiltration process.

With regards to the development of over producer strains, genetic manipulation of selected strains remains limited. Although recombinant strains of Bacillus sp. and Acinetobacter sp. have been described, most genetic manipulation efforts have been directed towards $P$. aeruginosa due in part to its commercial potential and the more detailed knowledge of its genome. Random mutagenesis using gamma-ray or $N$-methyl- $N$ '-nitrosoguanidine increased rhamnolipid production two- to threefold compared to wild strains (Mukherjee et al. 2006).

The ability to produce a hyper-producer strain of $P$. aeruginosa, however, is quite a difficult task due to the complexity of the transcriptional regulatory network of genes involved in rhamnolipid production. This is further complicated by the fact that rhamnolipids are produced as a mixture of congeners. Attempts have been made to limit the products to mono-rhamnolipids only through cloning the $P$. aeruginosa rhlABRI operon into host organisms such as E. coli or non-pathogenic P. putida (Cabrera-Valladares et al. 2006; Cha et al. 2008). Wang et al. (2007) also reported the use of genetic engineering to obtain an $E$. coli and $P$. aeruginosa that were able to produce rhamnolipids after transposonmediated chromosome integration of the rhamnosyltrasferase 1 complex. Further yield increase could probably be obtained once the regulation mechanism of biosurfactant production is fully elucidated (Hsueh et al. 2007).

\section{Conclusions and perspectives}

In bioremediation, biosurfactant applications are limited even though their high potential has been already demonstrated. This field will probably benefit more from recent and future research on the mechanisms of interactions among hydrocarbons, surfactants and cells than from case-specific studies about applicability of already-known biosurfactant compounds. In the food, biomedical and cosmetics area, in which high-value products are produced, the cost drawback could be less significant. The complex mixture of different components produced by organisms hampers applications, and further research is required to resolve specific issues. This field will have benefits from the very recent attention paid to the isolation and characterisation of biosurfactants produced by extremophiles such as thermophilic and halophilic bacteria (Mnif et al. 2009, Joshi et al. 2008; Kumar et al. 2008) aimed at the isolation of new compounds with novel properties.

The proven antimicrobial, anti-adhesive, immunemodulating properties of biosurfactants and the recent successful applications in gene therapy, immunotherapy and medical insertion safety suggest that it is worth persisting in this field. Advances in the area of biomedical application are probably going to take the lead due to higher potential economic returns. Moreover, due to their self-assembly properties, new and fascinating applications in nanotechnology are predicted for biosurfactants (Palanisamy 2008; Reddy et al. 2009, Kitamoto et al. 2009). In-depth studies of their natural roles in microbial competitive interactions, cell-to-cell communication, pathogenesis, motility and biofilm formation and maintenance could suggest future improved and interesting applications.

The commercial success of microbial surfactants is currently limited by the high cost of production. Optimised growth/production conditions using cheaper renewable substrates and novel and efficient multi-step downstream processing methods could make biosurfactant production more profitable and economically feasible. Furthermore, recombinant and mutant hyper-producer microbial strains, able to grow on a wide range of cheap substrates, could produce biosurfactants in high yield and, potentially, bring the required breakthrough for their economic production. 


\section{References}

Abalos A, Pinazo A, Infante MR, Casals M, García F, Manresa A (2001) Physicochemical and antimicrobial properties of new rhamnolipids produced by Pseudomonas aeruginosa AT10 from soybean oil refinery wastes. Langmuir 17:1367-1371

Agarwal P, Sharma DK (2009) Studies on the production of biosurfactant for the microbial enhanced oil recovery by using bacteria isolated from oil contaminated wet soil. Pet Sci Technol 27:1880-1893

Al-Ajiani MM, Sheikh MA, Ahmad Z, Hasnain S (2007) Production of surfactin from Bacillus subtilis MZ-7 grown on pharmamedia commercial medium. Microbial Cell Factory 6:17

Al-Tahhan RA, Sandrin TR, Bodour AA, Maier RM (2000) Rhamnolipid-induced removal of lipopolysaccharide from $\mathrm{Pseu}$ domonas aeruginosa: effect on cell surface properties and interaction with hydrophobic substrates. Appl Environ Microbiol 66:3262-3268

Arguelles-Arias A, Ongena M, Halimi B, Lara Y, Brans A, Joris B, Fickers P (2009) Bacillus amyloliquefaciens GA1 as a source of potent antibiotics and other secondary metabolites for biocontrol of plant pathogens. Microbial Cell Factory 8:63

Arima K, Kakinuma A, Tamura G (1968) Surfactin, a crystalline peptide-lipid surfactant produced by Bacillus subtilis: isolation, characterization and its inhibition of fibrin clot formation. Biochem Biophys Res Commun 31:488-494

Baltz RH, Miao V, Wrigley SK (2005) Natural products to drugs: daptomycin and related lipopeptide antibiotics. Nat Prod Rep 22:717-741

Banat IM (1995) Biosurfactants production and use in microbial enhanced oil recovery and pollution remediation: a review. Bioresour Technol 51:1-12

Banat IM, Makkar RS, Cameotra SS (2000) Potential commercial applications of microbial surfactants. Appl Microbiol Biotechnol 53:495-508

Bao MT, Kong XP, Jiang GC, Wang XL, Li XM (2009) Laboratory study on activating indigenous microorganisms to enhance oil recovery in Shengli oilfield. J Pet Sci Eng 66:42-46

Barkay T, Navon-Venezia S, Ron EZ, Rosenberg E (1999) Enhancement of solubilization and biodegradation of polyaromatic hydrocarbons by the bioemulsifier alasan. Appl Environ Microbiol 65:2697-2702

Basak P, Adhikari B, Banerjee I, Maiti TK (2009) Sustained release of antibiotic from polyurethane coated implant materials. J Mater Sci Mater Med 20:S213-S221

Bĕhal V (2006) Mode of action of microbial bioactive metabolites. Folia Microbiol 51:359-369

Benincasa M, Abalos A, Oliveira I, Manresa A (2004) Chemical structure, surface properties and biological activities of the biosurfactant produced by Pseudomonas aeruginosa LBI from soapstock. Anton Leeuw Int J G 85:1-8

Billingsley KA, Backus SM, Ward OP (1999) Effect of surfactant solubilization on biodegradation of polychlorinated biphenyl congeners by Pseudomonas LB400. Appl Microbiol Biotechnol $52: 255-260$

Boisselier E, Astruc D (2009) Gold nanoparticles in nanomedicine: preparations, imaging, diagnostics, therapies and toxicity. Chem Soc Rev 38:1759-1782

Bordoloi NK, Konwar BK (2008) Microbial surfactant-enhanced mineral oil recovery under laboratory conditions. Colloids Surf B Biointerfaces 63:73-82

Bordoloi NK, Konwar BK (2009) Bacterial biosurfactants in enhancing solubility and metabolism of petroleum hydrocarbons. $\mathrm{J}$ Hazardous Materials 170:495-505

Bouffioux O, Berquand A, Eeman M, Paquot M, Dufrêne YF, Brasseur R, Deleu M (2007) Molecular organization of surfactin-phospholipid monolayers: effect of phospholipid chain length and polar head. Biochim Biophys Acta Biomembr 1768:1758-1768

Brasseur R, Braun N, El Kirat K, Deleu M, Mingeot-Leclercq MP, Dufrêne YF (2007) The biologically important surfactin lipopeptide induces nanoripples in supported lipid bilayers. Langmuir 23:9769-9772

Byeon SE, Lee YG, Kim BH, Shen T, Lee SY, Park HJ, Park SC, Rhee MH, Cho JY (2008) Surfactin blocks NO production in lipopolysaccharide-activated macrophages by inhibiting NF-kB activation. J Microbiol Biotechnol 18:1984-1989

Cabrera-Valladares N, Richardson AP, Olvera C, Trevino LG, Deziel E, Lepine F, Soberon-Chavez G (2006) Monorhamnolipids and 3-(3-hydroxyalkanoyloxy)alkanoic acids (HAAs) production using Escherichia coli as a heterologous host. Appl Microbiol Biot 73:187-194

Çaglar E, Kargul B, Tanboga I (2005) Bacteriotherapy and probiotics' role on oral health. Oral Dis 11:131-137

Cameotra SS, Makkar RS (2004) Recent applications of biosurfactants as biological and immunological molecules. Curr Opin Microbiol 7:262-266

Cameotra SS, Singh P (2009) Synthesis of rhamnolipid biosurfactant and mode of hexadecane uptake by Pseudomonas species. Microb Cell Fact 8:16

Cao XH, Wang AH, Wang CL, Mao DZ, Lu MF, Cui YQ, Jiao RZ (2010) Surfactin induces apoptosis in human breast cancer MCF7 cells through a ROS/JNK-mediated mitochondrial/caspase pathway. Chem Biol Interact 183:357-362

Cha M, Lee N, Kim M, Lee S (2008) Heterologous production of Pseudomonas aeruginosa EMS1 biosurfactant in Pseudomonas putida. Bioresource Technol 99:2192-2199

Chang WN, Liu CW, Liu HS (2009) Hydrophobic cell surface and bioflocculation behavior of Rhodococcus erythropolis. Process Biochem 44:955-962

Chen HL, Juang RS (2008) Recovery and separation of surfactin from pretreated fermentation broths by physical and chemical extraction. Biochem Eng J 38:39-46

Chen HL, Chen YS, Juang RS (2008a) Recovery of surfactin from fermentation broths by a hybrid salting-out and membrane filtration process. Sep Purif Technol 59:244-252

Chen HL, Lee YS, Wei YH, Juang RS (2008b) Purification of surfactin in pretreated fermentation broths by adsorptive removal of impurities. Biochem Eng J 40:452-459

Chen XH, Koumoutsi A, Scholz R, Schneider K, Vater J, Süssmuth R, Piel J, Borriss R (2009) Genome analysis of Bacillus amyloliquefaciens FZB42 reveals its potential for biocontrol of plant pathogens. J Biotechnol 140:27-37

Chung YR, Kim CH, Hwang I, Chun J (2000) Paenibacillus koreensis sp. nov. A new species that produces an iturin-like antifungal compound. Int J Syst Evol Microbiol 50:1495-1500

Colores GM, Macur RE, Ward DM, Inskeep WPInskeep WP (2000) Molecular analysis of surfactant-driven microbial population shifts in hydrocarbon-contaminated soil. Appl Environ Microbiol 66:2959-2964

Das P, Mukherjee S, Sen R (2008a) Antimicrobial potential of a lipopeptide biosurfactant derived from a marine Bacillus circulans. J Appl Microbiol 104:1675-1684

Das P, Mukherjee S, Sen R (2008b) Improved bioavailability and biodegradation of a model polyaromatic hydrocarbon by a biosurfactant producing bacterium of marine origin. Chemosphere 72:1229-1234

Das P, Mukherjee S, Sen R (2009) Biosurfactant of marine origin exhibiting heavy metal remediation properties. Bioresour Technol 100:4887-4890

Dastgheib SMM, Amoozegar MA, Elahi E, Asad A, Banat IM (2008) Bioemulsifier production by a halothermophilic Bacillus strain 
with potential applications in microbially enhanced oil recovery. Biotechnol Lett 30:263-270

Debode J, De Maeyer K, Perneel M, Pannecoucque J, De Backer G, Höfte M (2007) Biosurfactants are involved in the biological control of Verticillium microsclerotia by Pseudomonas spp. J Appl Microbiol 103:1184-1196

Deleu M, Paquot M, Nylander T (2008) Effect of fengycin, a lipopeptide produced by Bacillus subtilis, on model biomembranes. Biophys J 94:2667-2679

Desai JD, Banat IM (1997) Microbial production of surfactants and their commercial potential. Microbiol Mol Biol Rev 61:47-64

Dimitrov K, Gancel F, Montastruc L, Nikov I (2008) Liquid membrane extraction of bio-active amphiphilic substances: recovery of surfactin. Biochem Eng J 42:248-253

Eeman M, Francius G, Dufrêne YF, Nott K, Paquot M, Deleu M (2009) Effect of cholesterol and fatty acids on the molecular interactions of fengycin with stratum corneum mimicking lipid monolayers. Langmuir 25:3029-3039

Federle MJ, Bassler BL (2003) Interspecies communication in bacteria. J Clin Invest 112:1291-1299

Francius G, Dufour S, Deleu M, Paquot M, Mingeot-Leclercq MP, Dufrêne YF (2008) Nanoscale membrane activity of surfactins: influence of geometry, charge and hydrophobicity. Biochim Biophys Acta 1778:2058-2068

Franzetti A, Di Gennaro P, Bevilacqua A, Papacchini M, Bestetti G (2006) Environmental features of two commercial surfactants widely used in soil remediation. Chemosphere 62:1474-1480

Franzetti A, Bestetti G, Caredda P, La Colla P, Tamburini E (2008a) Surface-active compounds and their role in the access to hydrocarbons in Gordonia strains. FEMS Microbiol Ecol 63:238-248

Franzetti A, Di Gennaro P, Bestetti G, Lasagni A, Pitea D, Collina E (2008b) Selection of surfactants for enhancing diesel hydrocarbons-contaminated media bioremediation. J Hazard Mater 152:1309-1316

Franzetti A, Caredda P, Ruggeri C, La Colla P, Tamburini E, Papacchini M, Bestetti G (2009a) Potential applications of surface active compounds by Gordonia sp. strain BS29 in soil remediation technologies. Chemosphere 75:810-807

Franzetti A, Caredda P, La Colla P, Pintus M, Tamburini E, Papacchini M, Bestetti G (2009b) Cultural factor affecting biosurfactant production by Gordonia sp. BS29. Int Biodeterior Biodegrad 63:943-947

Franzetti A, Tamburini E, Banat IM (2010) Application of biological surface active compounds in remediation technologies. In: Sen R (ed) Biosurfactants, 'Advances in experimental medicine and biology', vol 672. Springer, Berlin, pp 121-134

Glazyrina J, Junne S, Thiesen P, Lunkenheumer K, Goetz P (2008) In situ removal and purification of biosurfactants by automated surface enrichment. Appl Microbiol Biotechnol 81:23-31

Grangemard I, Wallach J, Maget-Dana R, Peypoux F (2001) Lichenysin: a more efficient cation chelator than surfactin. Appl Biochem Biotechnol 90:199-210

Grover M, Nain L, Singh SB, Saxena AK (2010) Molecular and biochemical approaches for characterization of antifungal trait of a potent biocontrol agent Bacillus subtilis RP24. Curr Microbiol 60:99-106

Gudiña EJ, Teixeira JA, Rodrigues LR (2010) Isolation and functional characterization of a biosurfactant produced by Lactobacillus paracasei. Colloids Surf B Biointerfaces 76:298-304

Gupta V, Garg R (2009) Probiotics. Indian J Med Microbiol 27:202209

Haddadin MSY, Abou Arqoub AA, Abu Reesh I, Haddadin J (2009) Kinetics of hydrocarbon extraction from oil shale using biosurfactant producing bacteria. Energy Convers Manag 50:983990
Han Y, Huang X, Cao M, Wang Y (2008) Micellization of surfactin and its effect on the aggregate conformation of amyloid $\beta(1-40)$. J Phys Chem B 112:15195-15201

Harriott MM, Noverr MC (2009) Candida albicans and Staphylococcus aureus form polymicrobial biofilms: effects on antimicrobial resistance. Antimicrob Agents Chemother 53:3914-3922

Hatakka K, Ahola AJ, Yli-Knuuttila H, Richardson M, Poussa T, Meurman JK (2007) Probiotics reduce the prevalence of oral Candida in the elderly - a randomized controlled trial. J Dent Res 86:125-130

Hawthorn LA, Reid G (1990) Exclusion of uropathogen adhesion to polymer surfaces by Lactobacillus acidophilus. J Biomed Mater Res 24:39-46

Hirata Y, Ryu M, Oda Y, Igarashi K, Nagatsuka A, Furuta T, Sugiura M (2009) Novel characteristics of sophorolipids, yeast glycolipid biosurfactants, as biodegradable low-foaming surfactants. J Biosci Bioeng 108:142-146

Hong HA, Duc LH, Cutting SM (2005) The use of bacterial spore formers as probiotics. FEMS Microbiol Rev 29:813-835

Hsueh YH, Somers EB, Lereclus D, Ghelardi E, Wong ACL (2007) Biosurfactant production and surface translocation are regulated by PlcR in Bacillus cereus ATCC 14579 under low-nutrient conditions. Appl Environ Microbiol 73:7225-7231

Huang X, Lu Z, Zhao H, Bie X, Lü FX, Yang S (2006) Antiviral activity of antimicrobial lipopeptide from Bacillus subtilis fmbj against pseudorabies virus, porcine parvovirus, newcastle disease virus and infectious bursal disease virus in vitro. Int $\mathrm{J}$ Pept Res Ther 12:373-377

Huang X, Lu Z, Bie X, Lü F, Zhao H, Yang S (2007) Optimization of inactivation of endospores of Bacillus cereus by antimicrobial lipopeptides from Bacillus subtilis fmbj strains using a response surface method. Appl Microbiol Biotechnol 74:454-461

Igarashi S, Hattori Y, Maitani Y (2006) Biosurfactant MEL-A enhances cellular association and gene transfection by cationic liposome. J Control Release 112:362-368

Imura T, Ito S, Azumi R, Yanagishita H, Sakai H, Abe M, Kitamoto D (2007) Monolayers assembled from a glycolipid biosurfactant from Pseudozyma (Candida) antarctica serve as a high-affinity ligand system for immunoglobulin $\mathrm{G}$ and $\mathrm{M}$. Biotechnol Lett 29:865-870

Imura T, Masuda Y, Ito S, Worakitkanchanakul W, Morita T, Fukuoka T, Sakai H, Abe M, Kitamoto D (2008) Packing density of glycolipid biosurfactant monolayers give a significant effect on their binding affinity toward immunoglobulin G. J Oleo Sci $57: 415-422$

Ito S, Imura T, Fukuoka T, Morita T, Sakai H, Abe M, Kitamoto D (2007) Kinetic studies on the interactions between glycolipid biosurfactant assembled monolayers and various classes of immunoglobulins using surface plasmon resonance. Colloids Surf B Bionterfaces 58:165-171

Joseph PJ, Joseph A (2009) Microbial enhanced separation of oil from a petroleum refinery sludge. J Hazard Mater 161:522525

Joshi S, Bharucha C, Jha S, Yadav S, Nerurkar A, Desai AJ (2008) Biosurfactant production using molasses and whey under thermophilic conditions. Bioresour Technol 99:195-199

Kaczorek E, Chrzanowski L, Pijanowska A, Oluanowski A (2008) Yeast and bacteria cell hydrophobicity and hydrocarbon biodegradation in the presence of natural surfactants: Rhamnolipids and saponins. Bioresource Technol 99:4285-4291

Kalmokoff ML, Austin JW, Wan XD, Sanders G, Banerjee S, Farber JM (2001) Adsoption, attachment and biofilm formation among isolates of Listeria monocytogenes using model conditions. J Appl Microbiol 91:725-734

Khardori N, Yassien MJ (1995) Biofilms in device-related infections. J Ind Microbiol 15:141-147 
Kim K, Yoo D, Kim Y, Lee B, Shin D, Kim E-K (2002) Characteristics sophorolipid as an antimicrobial agent. J Microbiol Biotechnol 12:235-241

Kim H, Ryu JH, Beuchat LR (2006) Attachment of and biofilm formation by Enterobacter sakazakii on stainless steel and enteral feeding tubes. Appl Environ Microbiol 72:5846-5856

Kitamoto D, Yanagishita H, Shinbo T, Nakane T, Kamisawa C, Nakahara T (1993) Surface active properties and antimicrobial activities of mannosylerythritol lipids as biosurfactants produced by Candida antarctica. J Biotechnol 29:91-96

Kitamoto D, Morita T, Fukuoka T, Konishi M, Imura T (2009) Selfassembling properties of glycolipid biosurfactants and their potential applications. Curr Opin Colloid Interface Sci 14:315328

Kõll P, Mändar R, Marcotte H, Leibur E, Mikelsaar M, Hammarström L (2008) Characterization of oral lactobacilli as potential probiotics for oral health. Oral Microbiol Immunol 23:139-147

Konishi M, Imura T, Fukuoka T, Morita T, Kitamoto D (2007a) A yeast glycolipid biosurfactant, mannosylerythritol lipid, shows high binding affinity towards lectins on a self-assembled monolayer system. Biotechnol Lett 29:473-480

Konishi M, Morita T, Fukuoha T, Imura T, Kakugawa K, Kitamoto D (2007b) Production of different types of mannosylerythritol lipids as biosurfactant by the newly isolated yeast strains belonging to the genus Pseudozyma. Appl Microbiol Biotechnol 75:521-531

Kronemberger FD, Anna L, Fernandes A, de Menezes RR, Borges CP, Freire DMG (2008) Oxygen-controlled biosurfactant production in a bench scale bioreactor. Appl Biochem Biotechnol 147:3345

Kulakovskaya T, Shashkov A, Kulakovskaya E, Golubev W, Zinin A, Tsvetkov Y, Grachev A, Nifantiev N (2009) Extracellular cellobiose lipid from yeast and their analogues: structures and fungicidal activities. J Oleo Sci 58:133-140

Kulakovskaya TV, Golubev WI, Tomashevskaya MA, Kulakovskaya EV, Shashkov AS, Grachev AA, Chizhov AS, Nifantiev NE (2010) Production of antifungal cellobiose lipids by Trichosporon porosum. Mycopathologia 169:117-123

Kumar M, Leon V, Materano ADS, Ilzins OA, Luis L (2008) Biosurfactant production and hydrocarbon-degradation by halotolerant and thermotolerant Pseudomonas sp. World J Microbiol Biotechnol 24:1047-1057

Landman D, Georgescu C, Martin DA, Quale J (2008) Polymyxins revisited. Clin Microbiol Rev 21:449-465

Maier RM, Soberón-Chávez G (2000) Pseudomonas aeruginosa rhamnolipids: biosynthesis and potential applications. Appl Microbiol Biotechnol 54:625-633

Maitani Y, Yano S, Hattori Y, Furuhata M, Hayashi K (2006) Liposome vector containing biosurfactant-complexed DNA as herpes simplex virus thymidine kinase gene delivery system. J Liposome Res 16:359-372

Makkar RS, Cameotra SS (2002) An update on the use of unconventional substrates for biosurfactant production and their new applications. Appl Microbiol Biot 58:428-434

Martinotti MG, Rivardo F Allegrone G, Ceri H, Turner R (2009) Biosurfactant composition produced by a new Bacillus licheniformis strain, uses and products thereof. International patent PCT/IB2009/055334 25 November

McCann MT, Gilmore BF, Gorman SP (2008) Staphylococcus epidermidis device-related infections: pathogenesis and clinical management. J Pharm Pharmacol 60:1551-1571

Merk K, Borelli C, Korting HC (2005) Lactobacilli-bacteria-host interactions with special regard to the urogenital tract. Int J Med Microbiol 295:9-18

Meurman JH (2005) Probiotics: do they have a role in oral medicine and dentistry? Eur J Oral Sci 113:188-196
Meurman JH, Stamatova I (2007) Probiotics: contributions to oral health. Oral Dis 13:443-445

Meylheuc T, Methivier C, Renault M, Herry JM, Pradier CM, Bellon-Fontaine MN (2006a) Adsorption on stainless steel surfaces of biosurfactants produced by gram-negative and gram-positive bacteria: consequence on the bioadhesive behavior of Listeria monocytogenes. Colloids Surf B Biointerfaces 52:128-137

Meylheuc T, Renault M, Bellon-Fontaine MN (2006b) Adsorption of a biosurfactant on surfaces to enhance the disinfection of surfaces contaminated with Listeria monocytogenes. Int J Food Microbiol 109:71-78

Miller RM, Zhang Y (1997) Measurement of biosurfactant-enhanced solubilization and biodegradation of hydrocarbons, bioremediation protocols. Humana Press, New Jersey, pp 59-66

Mimee B, Labbé C, Pelletier R, Bélanger RR (2005) Antifungal activity of flocculosin, a novel glycolipid isolated from Pseudozyma flocculosa. Antimicrob Agents Chemother 49:1597-1599

Mimee B, Pelletier R, Bélanger RR (2009) In vitro antibacterial activity and antifungal mode of action of flocculosin, a membrane-active cellobiose lipid. J Appl Microbiol 107:989-996

Mireles JR II, Toguchi A, Harshey RM (2001) Salmonella enterica serovar typhimurium swarming mutants with altered biofilm forming abilities: surfactin inhibits biofilm formation. J Bacteriol 183:5848-5854

Mnif S, Chamkha M, Sayadi S (2009) Isolation and characterization of Halomonas sp strain C2SS100, a hydrocarbon-degrading bacterium under hypersaline conditions. J Appl Microbiol 107:785-794

Mohammadipour M, Mousivand M, Salehi Jouzani G, Abbasalizadeh S (2009) Molecular and biochemical characterization of Iranian surfactin-producing Bacillus subtilis isolates and evaluation of their biocontrol potential against Aspergillus flavus and Colletotrichum gloeosporioides. Can J Microbiol 55:395404

Morikawa M (2006) Beneficial biofilm formation by industrial bacteria Bacillus subtilis and related species. J Biosci Bioeng $101: 1-8$

Morita T, Kitagawa M, Suzuki M, Yamamoto S, Sogabe A, Yanagidani S, Imura T, Fukuoka T, Kitamoto D (2009) A yeast glycolipid biosurfactant, mannosylerythritol lipid, shows potential moisturizing activity toward cultured human skin cells: the recovery effect of MEL-A on the SDS-damaged human skin cells. J Oleo Sci 58:639-642

Mukherjee AK (2007) Potential application of cyclic lipopeptide biosurfactants produced by Bacillus subtilis in laundry detergent formulations. Lett Appl Microbiol 45:330-335

Mukherjee S, Das P, Sen R (2006) Towards commercial production of microbial surfactants. Trends Biotechnol 24:509-515

Mulligan CN (2009) Recent advances in the environmental applications of biosurfactants. Curr Opin Colloid Interface Sci 14:372378

Mutalik SR, Vaidya BK, Joshi RM, Dsai KM, Nene SN (2008) Use of response surface optimization for the production of biosurfactant from Rhodococcus spp. MTCC 2574. Bioresour Technol 99:7875-7880

Nakanishi M, Inoh Y, Kitamoto D, Furuno T (2009) Nano vectors with a biosurfactant for gene transfection and drug delivery. J Drug Delivery Sci Technol 19:165-169

Naruse N, Tenmyo O, Kobaru S, Kamei H, Miyaki T, Konishi M, Oki T (1990) Pumilacidin, a complex of new antiviral antibiotics: production, isolation, chemical properties, structure and biological activity. J Antibiot (Tokyo) 43:267-280

Neu TR (1996) Significance of bacterial surface-active compounds in interaction of bacteria with interfaces. Microbiol Rev 60:151166 
Neu T, Hartner T, Poralla K (1990) Surface active properties of viscosin: a peptidolipid antibiotic. Appl Microbiol Biotechnol $32: 518-520$

Nitschke M, Costa SGVAO (2007) Biosurfactants in food industry. Trends Food Sci Technol 18:252-259

Nitschke M, Araújo LV, Costa SG, Pires RC, Zeraik AE, Fernandes AC, Freire DM, Contiero J (2009a) Surfactin reduces the adhesion of food-borne pathogenic bacteria to solid surfaces. Lett Appl Microbiol 49:241-247

Nitschke M, Costa SG, Contiero J (2009b) Structure and applications of a rhamnolipid surfactant produced in soybean oil waste. Appl Biochem Biotechnol 160:2066-2074. doi:10.1007/s12010-0098707-8

Noordman WH, Janssen DB (2002) Rhamnolipid stimulates uptake of hydrophobic compounds by Pseudomonas aeruginosa. Appl Environ Microbiol 68:4502-4508

Onaizi SA, He L, Middelberg APJ (2009) Rapid screening of surfactant and biosurfactant surface cleaning performance. Colloid Surf B 72:68-74

Ortiz A, Teruel JA, Espuny MJ, Marqués A, Manresa Á, Aranda FJ (2008) Interactions of a Rhodococcus sp. biosurfactant trehalose lipid with phosphatidylethanolamine membranes. Biochim Biophys Acta 1778:2806-2813

Ortiz A, Teruel JA, Espuny MJ, Marqués A, Manresa Á, Arand FJ (2009) Interactions of a bacterial biosurfactant trehalose lipid with phosphatidylserine membranes. Chem Phys Lipids 158:4653

Pal MP, Vaidya BK, Desai KM, Joshi RM, Nene SN, Kulkarni BD (2009) Media optimization for biosurfactant production by Rhodococcus erythropolis MTCC 2794: artificial intelligence versus a statistical approach. J Ind Microbiol Biotech 36:747756

Palanisamy P (2008) Biosurfactant mediated synthesis of NiO nanorods. Mat Lett 62:743-746

Palanisamy P, Raichur AM (2009) Synthesis of spherical NiO nanoparticles through a novel biosurfactant mediated emulsion technique. Mater Sci Eng C Biomim Supramol Syst 29:199-204

Paria S (2008) Surfactant-enhanced remediation of organic contaminated soil and water. Adv Colloid Interface Sci 138:24-58

Park SY, Kim Y (2009) Surfactin inhibits immunostimulatory function of macrophages through blocking NK-kB, MAPK and Akt pathway. Int Immunopharmacol 9:886-893

Peng F, Liu Z, Wang L, Shao Z (2007) An oil-degrading bacterium: Rhodococcus erythropolis strain 3C-9 and its biosurfactants. J Appl Microbiol 102:1603-1611

Perfumo A, Smyth TJP, Marchant R, Banat IM (2010a) Production and roles of biosurfactants and bioemulsifiers in accessing hydrophobic substrates. In: Timmis KN (ed) Handbook of hydrocarbon and lipid microbiology. Springer, Berlin, pp 15011512

Perfumo A, Rancich I, Banat IM (2010b) Possibilities and challenges for biosurfactants use in petroleum industry, vol 672. In: Sen R (ed) Biosurfactants' advances in experimental medicine and biology. Springer, Berlin, pp 135-157

Pissuwan D, Niidome T, Cortie MB (2009) The forthcoming applications of gold nanoparticles in drug and gene delivery systems. J Control Release (in press)

Pornsunthorntawee O, Arttaweeporn N, Paisanjit S, Somboonthanate P, Abe M, Rujiravanit R, Chavadej S (2008) Isolation and comparison of biosurfactants produced by Bacillus subtilis PT2 and Pseudomonas aeruginosa SP4 for microbial surfactantenhanced oil recovery. Biochem Eng J 42:172-179

Rapp P, Bock H, Wray V, Wagner F (1979) Formation, isolation and characterisation of trehalose dimycolates from Rhodococcus erythropolis grown on $n$-alkanes. J Gen Microbiol 115:491503
Rasmussen TB, Givskov M (2006) Quorum-sensing inhibitors as antipathogenic drugs. Int J Med Microbiol 296:149-161

Raza ZA, Rehman A, Khan MS, Khalid ZM (2007) Improved production of biosurfactant by Pseudomonas aeruginosa mutant using vegetable oil refinery wastes. Biodegradation $18: 115-121$

Raza ZA, Khalid ZM, Banat IM (2009) Characterization of rhamnolipids produced by a Pseudomonas aeruginosa mutant strain grown on waste oils. J Environ Sci Health Part A-Toxic/Hazard Substances Environ Eng 44:1367-1373

Reddy AS, Chen CY, Chen CC, Jean JS, Fan CW, Chen HR, Wang JC, Nimje VR (2009) Synthesis of gold nanoparticles via an environmentally benign route using a biosurfactant. J Nanosci Nanotechnol 9:6693-6699

Reid G, Burton J (2002) Use of Lactobacillus to prevent infection by pathogenic bacteria. Microbes Infect 4:319-324

Reid G, Bruce A, Smeianov V (1998) The role of Lactobacilli in preventing urogenital and intestinal infections. Int Dairy J 8:555562

Reid G, Bruce AW, Fraser N, Heinemann C, Owen J, Henning B (2001) Oral probiotics can resolve urogenital infections. FEMS Immunol Med Microbiol 30:49-52

Remichkova M, Galabova D, Roeva I, Karpenko E, Shulga A, Galabov AS (2008) Anti-herpesvirus activities of Pseudomonas sp. S-17 rhamnolipid and its complex with alginate. Z Naturforsch C 63:75-81

Rivardo F, Turner RJ, Allegrone G, Ceri H, Martinotti MG (2009) Anti-adhesion activity of two biosurfactants produced by Bacillus spp. prevents biofilm formation of human bacterial pathogens. Appl Microbiol Biotechnol 83:541-553

Rivardo F, Martinotti MG, Raymond Joseph Turner RJ, Ceri H (2010) The activity of silver against Escherichia coli biofilm is increased by a lipopeptide biosurfactant. Can J Microbiol 56(3):272-278. doi:10.1139/W10-007

Rocha MV, Souza MCM, Benedicto SC, Bezerra MS, Macedo GR, Pinto GAS, Goncalves LRB (2007) Production of biosurfactant by Pseudomonas aeruginosa grown on cashew apple juice. Appl Biochem Biotechnol 137-140:185-194

Rodrigues L, van der Mei HC, Teixeira J, Oliveira R (2004) Influence of biosurfactants from probiotic bacteria on formation of biofilms on voice prostheses. Appl Environ Microbiol 70:4408-4410

Rodrigues L, Banat IM, Teixeira J, Oliveira R (2006a) Biosurfactants: potential applications in medicine. J Antimicrob Chemother 57:609-618

Rodrigues L, van der Mei H, Banat IM, Teixeira J, Oliveira R (2006b) Inhibition of microbial adhesion to silicone rubber treated with biosurfactant from Streptococcus thermophilus A. FEMS Immunol Med Microbiol 46:107-112

Rodrigues LR, Banat IM, van der Mei HC, Teixeira JA, Oliveira R, Oliveira R (2006c) Interference in adhesion of bacteria and yeasts isolated from explanted voice prostheses to silicone rubber by rhamnolipid biosurfactants. J Appl Microbiol 100:470480

Rodrigues LR, Teixeira JA, van der Mei HC, Oliveira R (2006d) Physicochemical and functional characterization of a biosurfactant produced by Lactococcus lactis 53. Colloids Surf B Biointerfaces 49:79-86

Rodrigues L, Banat IM, Teixeira J, Oliveira R (2007) Strategies for the prevention of microbial biofilm formation on silicone rubber voice prostheses. J Biomed Mater Res B Appl Biomater 81:358 370

Rosenberg E, Ron EZ (1997) Bioemulsans: microbial polymeric emulsifiers. Curr Opin Biotechnol 8:313-316

Rosenberg E, Ron EZ (1999) High- and low-molecular-mass microbial surfactants. Appl Microbiol Biotechnol 52:154-162 
Rosenberg E, Rubinovitz C, Legmann R, Ron EZ (1987) Purification and chemical properties of Acinetobacter calcoaceticus A2 biodispersan. Appl Environ Microbiol 54:323-326

Ruggeri C, Franzetti A, Bestetti G, Caredda P, La Colla P, Pintus M, Sergi S, Tamburini E (2009) Isolation and characterisation of surface active compound-producing bacteria from hydrocarboncontaminated environments by a high-throughput screening procedure. Int Biodeterior Biodegrad 63:936-942

Saini HS, Barragán-Huerta BE, Lebrón-Paler A, Pemberton JE, Vázquez RR, Burns AM, Marron MT, Seliga CJ, Gunatilaka AA, Maier RM (2008) Efficient purification of the biosurfactant viscosin from Pseudomonas libanensis strain M9-3 and its physicochemical and biological properties. J Nat Prod 71:10111015

Sánchez M, Aranda FJ, Teruel JA, Ortiz A (2009) Interaction of a bacterial dirhamnolipid with phosphatidylcholine membranes: a biophysical study. Chem Phys Lipids 161:51-55

Sánchez M, Aranda FJ, Teruel JA, Espuny MJ, Marqués A, Manresa Á, Ortiz A (2010) Permeabilization of biological and artificial membranes by a bacterial dirhamnolipid produced by Pseudomonas aeruginosa. J Colloid Interface Sci 341:240-247

Selvam R, Maheswari P, Kavitha P, Ravichandran M, Sas B, Ramchand CN (2009) Effect of Bacillus subtilis PB6, a natural probiotic on colon mucosal inflammation and plasma cytokines levels in inflammatory bowel disease. Indian J Biochem Biophys 46:79-85

Sen R (2008) Biotechnology in petroleum recovery: the microbial EOR. Prog Energ Combust 34:714-724

Seydlová G, Svobodová J (2008) Review of surfactin chemical properties and the potential biomedical applications. Cent Eur J Med 3:123-133

Shah V, Doncel GF, Seyoum T, Eaton KM, Zalenskaya I, Hagver R, Azim A, Gross R (2005) Sophorolipids, microbial glycolipids with anti-human immunodeficiency virus and spermimmobilizing activities. Antimicrob Agents Chemother 49:4093-4100

Shreve GS, Inguva S, Gunnan S (1995) Rhamnolipid biosurfactant enhancement of hexadecane biodegradation by Pseudomonas aeruginosa. Mol Mar Biol Biotechnol 4:331-337

Singh P, Cameotra SS (2004) Potential applications of microbial surfactants in biomedical sciences. Trends Biotechnol 22:142146

Singh A, van Hamme JD, Ward OP (2007) Surfactants in microbiology and biotechnology: part 2. Application aspects. Biotechnol Adv 25:99-121

Sivapathasekaran C, Mukherjee S, Samanta R, Sen R (2009) Highperformance liquid chromatography purification of biosurfactant isoforms produced by a marine bacterium. Anal Bioanal Chem 395:845-854

Sivapathasekaran C, Mukherjee S, Ray A, Gupta A, Sen R (2010) Artificial neural network modeling and genetic algorithm based medium optimization for the improved production of marine biosurfactant. Bioresour Technol 101:2884-2887

Smyth TJP, Perfumo A, Marchant R, Banat IM (2010a) Isolation and analysis of low molecular weight microbial glycolipids. In: Timmis KN (ed) Handbook of hydrocarbon and lipid microbiology. Springer, Berlin, pp 3705-3723

Smyth TJP, Perfumo A, McClean S, Marchant R, Banat IM (2010b) Isolation and analysis of lipopeptides and high molecular weight biosurfactants. In: Timmis KN (ed) Handbook of hydrocarbon and lipid microbiology. Springer, Berlin, pp 3689-3704

Smyth TJ, Perfumo A, Marchant R, Banat IM, Chen M, Thomas RK, Penfold J, Stevenson PS, Parry NJ (2010c) Directed microbial biosynthesis of deuterated biosurfactants and potential future application to other bioactive molecules. Appl Microbiol Biotechnol (in press)
Snook ME, Mitchell T, Hinton DM, Bacon CW (2009) Isolation and characterization of Leu7-surfactin from the endophytic bacterium Bacillus mojavensis RRC 101, a biocontrol agent for Fusarium verticillioides. J Agric Food Chem 57:4287-4292

Sobrinho HBS, Rufino RD, Luna JM, Salgueiro AA, Campos-Takaki GM, Leite LFC, Sarubbo LA (2008) Utilization of two agroindustrial by-products for the production of a surfactant by Candida sphaerica UCP0995. Process Biochem 43:912-917

Sotirova AV, Spasova DI, Galabova DN, Karpenko E, Shulga A (2008) Rhamnolipid-biosurfactant permeabilizing effects on gram-positive and gram-negative bacterial strains. Curr Microbiol 56:639-644

Soudmand-Asli A, Ayatollahi SS, Mohabatkar H, Zareie M, Shariatpanahi SF (2007) The in situ microbial enhanced oil recovery in fractured porous media. J Pet Sci Eng 58:161-172

Stepanovic S, Cirkovic I, Ranin L, Svabic-Vlahovic M (2004) Biofilm formation by Salmonella spp. and Listeria monocytogenes on plastic surface. Lett Appl Microbiol 38:428-432

Suthar H, Hingurao K, Desai A, Nerurkar A (2008) Evaluation of bioemulsifier mediated microbial enhanced oil recovery using sand pack column. J Microbiol Methods 75:225-230

Tanaka Y, Tojo T, Uchida K, Uno J, Uchida Y, Shida O (1997) Method of producing iturin A and antifungal agent for profound mycosis. Biotechnol Adv 15:234-235

Teichmann B, Linne U, Hewald S, Marahiel MA, Bölker M (2007) A biosynthetic gene cluster for a secreted cellobiose lipid with antifungal activity from Ustilago maydis. Mol Microbiol 66:525533

Thavasi R, Jayalakshmi S, Balasubramanian T, Banat IM (2007) Biosurfactant production by Corynebacterium kutscheri from waste motor lubricant oil and peanut oil cake. Lett Appl Microbiol 45:686-691

Thavasi R, Jayalakshmi S, Balasubramanian T, Banat IM (2008) Production and characterization of a glycolipid biosurfactant from Bacillus megaterium using economically cheaper sources. World J Microbiol Biotechnol 24:917-925

Tiehm A (1994) Degradation of polycyclic aromatic hydrocarbons in the presence of synthetic surfactants. Appl Environ Microbiol 60:258-263

Tran H, Ficke A, Asiimwe T, Höfte M, Raaijmakers JM (2007) Role of cyclic lipopeptide massetolide A in biological control of Phytophthora infestans and in colonization of tomato plants by Pseudomonas fluorescens. New Phytol 175:731-742

Tran H, Kruijt M, Raaijmakers JM (2008) Diversity and activity of biosurfactant-producing Pseudomonas in the rhizosphere of black pepper in Vietnam. J Appl Microbiol 104:839-851

Ueno Y, Hirashima N, Inoh Y, Furuno T, Nakanishi M (2007a) Characterization of biosurfactant-containing liposomes and their efficiency for gene transfection. Biol Pharm Bull 30:169-172

Ueno Y, Inoh Y, Furuno T, Hirashima N, Kitamoto D, Nakanishi M (2007b) NBD-conjugated biosurfactant (MEL-A) shows a new pathway for transfection. J Control Release 123:247-253

Valle J, Da Re S, Henry N, Fontaine T, Balestrino D, Latour-Lambert P, Ghigo JM (2006) Broad-spectrum biofilm inhibition by a secreted bacterial polysaccharide. Proc Natl Acad Sci U S A 103:12558-12563

Van Bogaert INA, Saerens K, De Muynck C, Develter D, Wim S, Vandamme EJ (2007) Microbial production and application of sophorolipids. Appl Microbiol Biotechnol 76:23-34

Van Hamme JD, Singh A, Ward OP (2006) Physiological aspects Part 1 in a series of papers devoted to surfactants in microbiology and biotechnology. Biotechnol Adv 24:604-620

Van Hoogmoed CG, Van der Mei HC, Busscher HJ (2004) The influence of biosurfactants released by $S$. mitis BMS on the adhesion of pioneer strains and cariogenic bacteria. Biofouling $20: 261-267$ 
Van Hoogmoed CG, Dijkstra RJB, van der Mei HC, Busscher HJ (2006) Influence of biosurfactant on interactive forces between mutans streptococci and enamel measured by atomic force microscopy. J Dent Res 85:54-58

Varnier AL, Sanchez L, Vatsa P, Boudesocque L, Garcia-Brugger A, Rabenoelina F, Sorokin A, Renault JH, Kauffmann S, Pugin A, Clement C, Baillieul F, Dorey S (2009) Bacterial rhamnolipids are novel MAMPs conferring resistance to Botrytis cinerea in grapevine. Plant Cell Environ 32:178-193

Vater J, Kablitz B, Wilde C, Frank P, Mehta N, Cameotra SS (2002) Matrix-assisted laser desorption ionization time of flight mass spectrometry of lipopeptide biosurin whole cells and culture filtrates of Bacillus subtilis C-1 isolated from petroleum sludge. Appl Environ Microbiol 68:6210-6219

Velmurugan N, Choi MS, Han SS, Lee YS (2009) Evaluation of antagonistic activities of Bacillus subtilis and Bacillus licheniformis against wood-staining fungi: in vitro and in vivo experiments. J Microbiol 47:385-392

Velraeds MCM, van der Mei HC, Reid G, Busscher HJ (1996) Physicochemical and biochemical characterization of biosurfactants released by Lactobacillus strains. Colloids Surf B 8:51-61

Velraeds MM, van de Belt-Gritter B, Busscher HJ, Reid G, Van der Mei HC (2000) Inhibition of uropathogenic biofilm growth on silicone rubber in human urine by lactobacilli-a teleologic approach. World J Urol 18:422-426

Vinh DC, Embil JM (2005) Device-related infections: a review. J Long Term Eff Med Implants 15:467-488

Volkering F, Breure AM, Rulkens WH (1998) Microbiological aspects of surfactant use for biological soil remediation. Biodegradation 8:401-417

Vollenbroich D, Ozel M, Vater J, Kamp RM, Pauli G (1997) Mechanism of inactivation of enveloped viruses by the biosurfactant surfactin from Bacillus subtilis. Biologicals 25:289-297

von Eiff C, Kohnen W, Becker K, Jansen B (2005) Modern strategies in the prevention of implant-associated infections. Int $\mathrm{J}$ Artif Organs 28:1146-1156
Walencka E, Różalska S, Sadowska B, Różalska B (2008) The influence of Lactobacillus acidophilus derived surfactants on staphylococcal adhesion and biofilm formation. Folia Microbiol 53:61-66

Wang SL, Mulligan CN (2009) Arsenic mobilization from mine tailings in the presence of a biosurfactant. Appl Geochem 24:928-935

Wang Q, Fang X, Bai B, Liang X, Shuler PJ, Goddard WA III, Tang Y (2007) Engineering bacteria for production of rhamnolipid as an agent for enhanced oil recovery. Biotechnol Bioeng 98:842853

Wang J, Ma T, Zhao L, Lv J, Li G, Zhang H, Zhao B, Liang F, Liu R (2008) Monitoring exogenous and indigenous bacteria by PCRDGGE technology during the process of microbial enhanced oil recovery. J Ind Microbiol Biotechnol 35:619-628

Wen J, Stacey SP, McLaughlin MJ, Kirby JK (2009) Biodegradation of rhamnolipid, EDTA and citric acid in cadmium and zinc contaminated soils. Soil Biol Biochem 41:2214-2221

Xu T, Chen C, Liu C, Zhang S, Wu Y, Zhang P (2009) A novel way to enhance the oil recovery ratio by Streptococcus sp. BT-003. J Basic Microbiol 49:477-481

Yakimov MM, Timmis KN, Wray V, Fredrickson HL (1995) Characterization of a new lipopeptide surfactant produced by thermotolerant and halotolerant subsurface Bacillus licheniformis BAS 50. Appl Environ Microbiol 61:1706-1713

Zaragoza A, Aranda FJ, Espuny MJ, Teruel JA, Marqués A, Manresa Á, Ortiz A (2009) A mechanism of membrane permeabilization by a bacterial trehalose lipid biosurfactant produced by Rhodococcus sp. Langmuir 25:7892-7898

Zheng YG, Chen XL, Shen YC (2008) Commodity chemicals derived from glycerol, an important biorefinery feedstock. Chem Rev 108:5253-5277

Zhong H, Zeng GM, Yuan XZ, Fu HY, Huang GH, Ren FY (2007) Adsorption of dirhamnolipid on four microorganisms and the effect on cell surface hydrophobicity. Appl Microbiol Biot $77: 447-455$ 